\title{
A POLÍTICA, O DIREITO E O DESENVOLVIMENTO: UM ESTUDO SOBRE A TRANSPOSIÇÃO DO RIO SÃO FRANCISCO
}

\section{RESUMO}

ESTE ARTIGO ANALISA SOB O CONTEXTO HISTÓRICO-JURÍDICO A DECISÃO (POLITICA E JURÍDICA) DE TRANSPOR O RIO SÃo FRANCISCO COM O OBJETIVO GERAL DE DEMONSTRAR QUE A PROMESSA DE DESENVOLVIMENTO ECONÔMICO SEM CONSIDERAR ADEQUADAMENTE A DIMENSÃO AMBIENTAL E A SOCIAL LEGARÁ À SOCIEDADE BRASILEIRA, EM ESPECIAL A DO SEMIÁRIDO, IMPACTOS, DANOS E RISCOS AMBIENTAIS, ALÉM DOS ALTOS CUSTOS FINANCEIROS DE SUA MANUTENCÃO. OBJETIVA-SE TAMBÉM RESGATAR A HISTÓRIA DA TRANSPOSIC̣ĀO dO RIO SÃo FRANCISCO, APRESENTAR O PROJETO DE TRANSPOSIC̣ÃO DO GOVERNO LULA E DEMONSTRAR COMO O DIREITO AMBIENTAL brasileiro, o Plano Decenal da Bacia do Rio São Francisco E A OPINIÃO POPULAR FORAM DESRESPEITADOS NA DECISÃO DE TRANSPOR O RIO SÃO FRANCISCO. A PESQUISA É DE CUNHO TEÓRICO-PRÁTICO, TENDO-SE ADOTADO O MÉTODO DE ABORDAGEM INDUTIVO E UM EXTENSO ROL DE FONTES BIBLIOGRÁFICAS E DOCUMENTAIS. A PARTIR DA PESQUISA, CONCLUIU-SE QUE A DECISÃO DE TRANSPOR O RIO SÃO FRANCISCO EM PROL DO DESENVOLVIMENTO ECONÔMICO COM A CHANCELA DO PODER JUDICIÁRIO (STF). DESCONSIDEROU A OPINIÃo POPULAR, O PLANO DECENAL DA BACIA DO RIO SÃO FRANCISCO, ASPECTOS DO DIREITO AMBIENTAL BRASILEIRO (PRINCÍPIOS DA PREVENÇÃOO, PRECAUÇÃO, PARTICIPAÇÃO POPULAR ETC.) E A BUSCA PELO DESENVOLVIMENTO SUSTENTÁVEL.

\section{PALAVRAS-CHAVE}

Transposição do rio São Francisco; Direito ambiental; Desenvolvimento sustentável; Decisões; Riscos.

\author{
Silviana L. Henkes \\ POLITICS, LAW AND DEVELOPMENT: \\ A STUDY ON THE TRANSPOSITION OF THE SÃO FRANCISCO RIVER
}

\begin{abstract}
THIS PAPER EXAMINES IN HISTORICAL AND LEGAL CONTEXT THE DECISION (POLITICAL AND LEGAL) OF TRANSPOSING THE SAO FRANCISCO RIVER, WITH THE OVERALL OBJECTIVE OF DEMONSTRATING THAT THE PROMISE OF ECONOMIC DEVELOPMENT WITHOUT ADEQUATELY CONSIDERING THE ENVIRONMENTAL AND SOCIAL ASPECTS WILL BEQUEATH TO THE BRAZILIAN SOCIETY, ESPECIALLY THE SEMI-ARID, ENVIRONMENT, IMPACTS, ENVIRONMENTAL DAMAGE AND RISKS, IN ADDITION TO HIGH FINANCIAL COSTS OF MAINTAINING IT. IT ALSO AIMS TO RESCUE THE HISTORY OF THE SÃO FRANCISCO TRANSPOSITION; PRESENT THE PROJECT FOR TRANSPOSITION OF PRESIDENT LULA; DEMONSTRATE HOW THE BRAZILIAN ENVIRONMENTAL LAW, the Ten Year Plan of the São Francisco RIVER Basin AND POPULAR OPINION WERE DISREGARDED IN THE DECISION TO TRANSPOSE THE SAN FRANCISCO RIVER. FOR THIS STUDY THE INDUCTIVE METHOD WAS ADOPTED AND PRIMARY AND SECONDARY SOURCES WERE USED. THROUGH RESEARCH IT WAS CONCLUDED THAT THE DECISION TO CROSS THE SAN FRANCISCO RIVER IN SUPPORT OF ECONOMIC DEVELOPMENT WITH THE SEAL OF THE JUDICIARY (STF), DISREGARDS THE POPULAR BELIEF, THE TEN YEAR Plan of THE SÃo FranCISCO RIVER BASIN, THE ENVIRONMENTAL LAW IN USE, AND THE PURSUIT OF SUSTAINABLE DEVELOPMENT.
\end{abstract}

\section{KEYWORDS}

TRANSPOSITION OF SÃO FRANCISCO RIVER; ENVIRONMENTAL LaW; Sustainable DEVElopment; DeCISIONS; RISKS. 


\section{INTRODUÇÃO}

O Governo brasileiro vem executando e planejando grandes obras de infraestrutura (construção de rodovias, hidrelétricas, aeroportos etc.) na expectativa e promessa de desenvolvimento do país ou de determinadas regiões, como a do Semiárido Nordestino. Neste caso, por meio da transposição do rio São Francisco. Deste modo, torna-se indispensável analisar a efetividade do Direito e o papel do operador jurídico para a promoção da sustentabilidade. E, ainda, refletir sobre as consequências das decisões (políticas e jurídicas) no intuito de (re)pensar as escolhas futuras.

Importa salientar desde já que a execução das obras de infraestrutura, muitas delas planejadas pelo Governo Federal por meio dos Programas de Aceleração do Crescimento (PAC), tem repercussões positivas para a sociedade brasileira, em especial no âmbito econômico e com interfaces no campo social, como a geração de empregos e o aumento da circulação de renda. Contudo, a tomada de decisão, política e jurídica, não deve olvidar a dimensão ambiental e social, a fim de que o desenvolvimento almejado seja justo e sustentável. A maioria das obras de infraestrutura em execução ou planejadas no âmbito do PAC têm direta, complexa e irreversível interferência no meio ambiente, razão pela qual a sustentabilidade ambiental e a viabilidade técnica, além da econômica, e a aceitabilidade social, devem ser comprovadas.

Neste sentido, este artigo abordará sob o enfoque histórico-jurídico a transposição do rio São Francisco com o objetivo geral de demonstrar o desrespeito a preceitos importantes do ordenamento jurídico, em especial, do direito ambiental, em prol da promessa de desenvolvimento econômico. A transposição é defendida pelo Governo Federal como a solução para os problemas do Semiárido Nordestino por meio do esperado desenvolvimento econômico da região com o aumento das fontes de trabalho e fixação da população na região.

Não obstante, os impactos, danos e riscos ambientais (sociedade e natureza) foram minimizados ou desconsiderados pelo Governo Federal (Presidência da República, Secretarias, Ibama, ANA, MIN etc.) e, em especial, no Relatório de Impacto ao Meio Ambiente (RIMA). Muitos estudos e, inclusive, o RIMA atestam que a obra ocasionará a perda e a extinção de espécies da flora e fauna, interferências em espaços protegidos, aumento e/ou aparecimento de doenças, acidentes com a população, ruptura de relações sociocomunitárias, introdução de riscos e tensões sociais, portanto, acenando para a sua insustentabilidade etc.

O estudo tem como objetivos específicos: a) resgatar a história da transposição do rio São Francisco; b) apresentar o projeto da transposição; c) demonstrar como alguns preceitos do direito ambiental brasileiro foram desrespeitados na decisão de transpor o rio São Francisco, em especial, os princípios de prevenção, precaução e participação; e d) mostrar os impactos, danos e riscos ambientais decorrentes da obra demonstrando a sua insustentabilidade. 
Para a realização deste estudo, adotou-se o método indutivo, foi usado amplo rol bibliográfico e documental. Foi estabelecida a seguinte hipótese de pesquisa: a decisão de transpor o rio São Francisco em prol do desenvolvimento econômico com a chancela do Poder Judiciário (STF) desconsidera preceitos do direito ambiental vigente e a busca pelo desenvolvimento sustentável.

\section{i A história da transposição do rio SÃo Francisco}

Desde o século XIX, a transposição do rio São Francisco vem sendo defendida como a solução para “os problemas do Nordeste”. A primeira proposta, ainda que muito vaga, tratava da abertura de um canal que levasse água do rio São Francisco ao rio Jaguaribe, idealizada no século XIX, pelo ouvidor José Raimundo dos Passos Barbosa, em 1818 (VILLA, 2004, p. 1). ${ }^{1}$

Pouco tempo depois, Dom Pedro II também passou a defender a transposição como o meio mais eficaz de lidar com as secas no Nordeste e o Projeto de Transposição do rio São Francisco começou a ser delineado. Por volta de 1850, o engenheiro Henrique Fernando Halfeld foi encarregado pelo Governo Imperial de fazer um estudo sobre o rio, publicado em 1860, sob o título "Atlas de relatório concernente à exploração do rio São Francisco desde a cachoeira da Pirapora até ao Oceano Atlântico” (VILLA, 2004, p. 1). Neste estudo, o Engenheiro Halfeld defendeu a ideia de transpor as águas do rio São Francisco para o rio Jaguaribe, identificando o ponto para a retirada das águas em Cabrobó (PE) (LEITE, 2005, p. 7).

As ideias de Dom Pedro II foram esquecidas até que em 1912 (século XX), com a criação da Inspetoria Federal de Obras contra a Seca (IOCS), o projeto voltou à pauta. Contudo em 1920, foi descartado como inviável, pois à época não existia tecnologia capaz de superar as barreiras do relevo, superiores a 200 metros. Em 1959, um século depois da publicação do relatório de Halfeld, o Presidente Juscelino Kubitschek criou a Superintendência do Desenvolvimento do Nordeste (Sudene), confiada ao Ministro Celso Furtado que não defendia abertamente a transposição por temer os riscos da salinização do solo nas áreas irrigadas e então o projeto foi arquivado (LEITE, 2005, p. 7).

No Governo de Figueiredo (1979-1985), o Ministro do Interior, Mário Andreazza, resgatou o projeto em 1980. Seus planos fluíram até 1984, quando uma grande mortandade de peixes no rio São Francisco fez com que o projeto fosse engavetado (LEITE, 2005, p. 7).

No Governo Itamar (1992-1995), a ideia voltou à cena outra vez. Em 1994, nas mãos dos Ministros da Integração Regional, Aluízio Alves e do Planejamento, Beni Veras. Nesse governo, deu-se início ao licenciamento ambiental, formulando-se o Termo de Referência para o EIA/RIMA, em 10/05/1994. Na época, pensava-se em retirar 7,5\% da vazão do rio para a obra, contra os 1,5\% do atual (VILLA, 2004, p. 1; LEITE, 2005, p. 7; BAHIA, 2006, p. 1). 
No pleito eleitoral para a presidência da República (1994), o candidato Fernando Henrique Cardoso não se manifestava diretamente sobre a transposição. Depois de eleito (1996), destinou $\mathrm{R} \$ 500$ milhões para a retomada do projeto (LEITE, 2005, p. 7). Em junho de 1996, o Ministério do Planejamento e Orçamento requereu a concessão da licença prévia para o empreendimento (licenciamento iniciado no Governo Itamar) (BAHIA, 2006, p. 1). Em 1998, ano eleitoral, o candidato à reeleição FHC tornou-se um grande defensor da transposição, mas numa versão mais racional, com vazões muito menores que as propostas anteriores. Na busca da reeleição, FHC transformou a transposição em um dos pontos de destaque do seu plano desenvolvimentista "Avança Brasil” (LEITE, 2005, p. 7).

Em 11/01/2000, o pedido de licença prévia foi renovado pelo Ministério da Integração Nacional que protocolou o EIA/RIMA em 03/07/2000. Após a realização de algumas adequações no EIA/RIMA determinadas pelo Ibama e a disponibilização do seu conteúdo ao público, foram definidas as datas de realização das audiências públicas. ${ }^{2}$ Contudo, em decorrência das falhas detectadas no EIA/RIMA e da necessidade de complementação dos estudos de impacto ambiental, representantes do Ministério Público ingressaram com representação criminal e ação por improbidade administrativa no Ministério Público Federal do Distrito Federal contra o presidente e o diretor do licenciamento do Ibama. O projeto de transposição e o licenciamento tiveram outros embargos judiciais. ${ }^{3}$

Encerrados os mandatos de FHC (1995-2002), as obras não tinham saído do papel ante o embargo judicial, sendo o projeto abandonado em 2001 (BAHIA, 2006, p. 1-4; LEITE, 2005, p. 7). A grave crise energética - "apagão" - ocorrida no Brasil, a partir de abril de 2001, cujo apogeu deu-se na segunda metade daquele ano, contribuiu sobremaneira para o projeto ser esquecido (CAUBET; ARAÚJO, 2004, p. 168).

No pleito eleitoral para o governo federal (2002), o então candidato à presidência Luís Inácio Lula da Silva, não defendia abertamente a transposição. ${ }^{4}$ Contudo, após eleito, em seu primeiro mandato (2003-2006), tornou-se um defensor do projeto e elegeu a transposição uma das principais obras de seu governo (COELHO, 2004, p. 2). O então Presidente Lula deu "carta branca" ao Ministro da Integração Nacional, Ciro Gomes para retomar o processo de licenciamento paralisado e o Governo apresentou um novo estudo de impacto ambiental ao Ibama, em 12/07/2004. Este estudo também continha diversas falhas, detectadas por vários órgãos que procederam à sua análise.

Depois de várias tentativas inexitosas, a ideia de transpor as águas do rio São Francisco saiu do papel no primeiro mandato do Governo Lula (2003-2006). Ao contrário dos projetos anteriores, este vem resistindo até a data de publicação deste artigo (dez/2014), às inúmeras contestações judiciais e sociais. Saliente-se que, além da forte vontade política (Governo Federal e de alguns governos estaduais), as condições 
econômicas do país, bem como o acesso a novas tecnologias, favorecem a sua execução, ao contrário dos anteriores.

Desse modo, faz-se necessário apresentar, ainda que em breves linhas, o Projeto de Transposição do rio São Francisco concebido pelo Governo Lula e executado pelo Governo Dilma, antes de analisar seus imbróglios jurídicos.

\section{i. I O Projeto de Transposição do Rio São Francisco do Governo Lula}

O Projeto de Transposição idealizado pelo Governo Lula - e que vem sendo executado pelo Governo Dilma - tem como objetivo captar água em dois pontos do rio São Francisco e levá-la ao Semiárido Nordestino para prover água às populações; assegurar safras agrícolas, atividades industriais e o turismo; fixar a população rural na região; promover o crescimento das atividades produtivas; diminuir gastos públicos com medidas emergenciais durante as frequentes secas; garantir água para uma infraestrutura de reserva e distribuição já existente (açudes, rios e adutoras), enfim, segundo o Governo, promover o desenvolvimento (RIMA, 2004).

A distribuição da água se dará por meio de dois eixos. O Eixo Norte (Latitude Sul 08 32'41,1" e Longitude Oeste 39 27'15,2”) visa atingir Pernambuco (PE), Ceará (CE), Paraíba (PB) e Rio Grande do Norte (RN) - destes somente o Estado de Pernambuco faz parte da bacia. E o Eixo Leste (Latitude Sul 08 49'37,7” e Longitude Oeste $\left.38^{\circ} 24^{\prime} 43,3^{\prime \prime}\right)$ que beneficiará parte do Sertão e as regiões agrestes de Pernambuco e da Paraíba.

O primeiro ponto de captação (Eixo Norte) está nas proximidades da cidade de Cabrobó (PE) e percorrerá cerca de $400 \mathrm{~km}$ conduzindo água aos rios Salgado e Jaguaribe, no Ceará; Apodi, no Rio Grande do Norte; Piranhas-Açu, na Paraíba e Rio Grande do Norte. Ao cruzar o Estado de Pernambuco, este eixo conduzirá água para suprir as demandas de municípios inseridos em três sub-bacias do rio São Francisco: Brígida, Terra Nova e Pajeú. Para atender a região do rio Brígida, no Oeste de Pernambuco, foi concebido um ramal de $110 \mathrm{~km}$ de comprimento que derivará parte da vazão do Eixo Norte para os açudes Entre Montes e Chapéu. Projetado para uma capacidade máxima de $99 \mathrm{~m}^{3} / \mathrm{s}$, este eixo operará com uma vazão contínua de $16,4 \mathrm{~m}^{3} / \mathrm{s}$. Em períodos recorrentes de escassez hídrica nas bacias receptoras e de abundância na bacia do São Francisco, as vazões transferidas poderão atingir a capacidade máxima estabelecida. Os volumes excedentes transferidos serão armazenados em reservatórios existentes nas bacias receptoras: Atalho e Castanhão, no Ceará; Armando Ribeiro Gonçalves, Santa Cruz e Pau dos Ferros, no Rio Grande do Norte; Engenheiro Ávido e São Gonçalo, na Paraíba; Chapéu e Entre Montes, em Pernambuco.

O Eixo Leste terá a captação no lago da Barragem de Itaparica, no município de Floresta (PE) e percorrerá $220 \mathrm{~km}$ até o rio Paraíba (PB), após deixar parte da vazão nas bacias do Pajeú, do Moxotó e da região Agreste de Pernambuco. Para o atendimento da 
demanda da região Agreste de Pernambuco, o projeto prevê a construção de um ramal de 70 km que o interligará à Bacia do rio Ipojuca. Previsto para uma capacidade máxima de $28 \mathrm{~m}^{3} / \mathrm{s}$, este eixo funcionará com uma vazão contínua de $10 \mathrm{~m}^{3} / \mathrm{s}$.

Os dois eixos terão capacidade máxima de $127 \mathrm{~m}^{3} / \mathrm{s}$ (99 no Eixo Norte e 28 no Leste). Esta vazão, segundo o Ministério da Integração Nacional, será utilizada somente quando a barragem do Sobradinho (BA) estiver cheia (mais de 94\% de sua capacidade). A vazão prevista para 2013 era de $26,4 \mathrm{~m}^{3} / \mathrm{s}\left(16,4 \mathrm{~m}^{3} / \mathrm{s}\right.$ no Eixo Norte e $10 \mathrm{~m}^{3} / \mathrm{s}$ no Leste), correspondente a $1,5 \%$ da vazão mínima ${ }^{5}$ do rio. Em 2025, será de $63,5 \mathrm{~m}^{3} / \mathrm{s}\left(42,4 \mathrm{~m}^{3} / \mathrm{s}\right.$ no Eixo Norte e $21,1 \mathrm{~m}^{3} / \mathrm{s}$ no Eixo Leste).

Em razão da paralisação de alguns trechos das obras, a vazão prevista para 2013 foi estimada para ser utilizada somente em 2015, data que o Governo Federal estima para a entrega da primeira parte das obras (site do Ministério da Integração Nacional). Convém salientar que, após a repercussão na mídia, durante o ano de 2012, acerca do estado de deterioração das obras da transposição, haja vista a paralisação da execução de sete dos dezenove trechos, e também da suspeita de irregularidades nos contratos de obras e serviços em cinco trechos, o Governo Federal noticiou que já tinha tomado as medidas cabíveis e que as obras seriam retomadas durante 2013, após a conclusão de novas licitações para saldos remanescentes (site do Ministério da Integração Nacional).

Atualmente, segundo informações do Governo Federal (site do Ministério da Integração Nacional), as obras físicas do Projeto apresentam 69,2\% de execução e todas as etapas têm $100 \%$ de contratação, com previsão de entrega para o primeiro semestre de 2016. Contudo, o Ministério da Integração Nacional, em seu site, ainda mantém o prazo de conclusão das obras para 2015.

O valor inicial estimado para a execução do projeto era de R \$ 3 bilhões (para construir os canais de concreto, estações de bombeamento e reservatórios) (MINISTÉRIO DA INTEGRAÇÃO NACIONAL, 2004b, p. 38), mas que ainda devem ser contabilizados os gastos relativos à manutenção e à operacionalização do sistema, estimados em R\$ 127 milhões que ficarão a cargo dos Estados "beneficiados" (CE, PE PB, RN) (SALOMON, 2004, p. especial 3; AB'SÁBER, 2005b, p. A18). O orçamento foi revisto e a previsão atual é de que sejam gastos $\mathrm{R} \$ 8$ bilhões (site do Ministério da Integração Nacional).

Importa salientar que diversas irregularidades quanto ao pagamento e sobrepreço das obras da transposição foram constatadas pelo Tribunal de Contas da União (TCU) com publicação no D.O.U. em 06/11/2006, por meio do Acórdão n. 2.017/2006, dentre elas estão: sobrefaturamento; falhas no orçamento; descumprimento de normas ambientais e de cronogramas financeiros. OTCU também recomendou que fossem suspensos os recursos financeiros e os pagamentos realizados sejam devolvidos aos cofres públicos até decisão judicial final sobre o Projeto. 


\section{A oposição e os principais entraves jurídicos ao Projeto de Transposição do Rio São Francisco do Governo lula}

\section{I As AÇÕES JUDICIAIS}

Foram inúmeras ações judiciais propostas para impedir a execução do Projeto de Transposição do rio São Francisco tanto pelas falhas apresentadas no licenciamento quanto pela inaceitabilidade da obra por parte da comunidade científica e dos povos afetados, haja vista os danos ambientais comprovados.

Os entraves jurídicos ${ }^{6}$ iniciaram com a retomada do processo de licenciamento ambiental quando da apresentação do novo EIA/RIMA. Diversas entidades ambientalistas impetraram ações contra atos do Ibama (concessão da licença), da ANA (concessão da outorga hídrica) e do Ministério da Integração Nacional (planejamento e execução do projeto de transposição). O trabalho abordará as principais, haja vista o grande número de ações propostas.

Ainda com as ações judiciais contra a transposição em trâmite, foi anunciado (novembro de 2004), em regime de urgência, uma reunião do Conselho Nacional de Recursos Hídricos (CNRH), para o dia 30/11/2004, tornando possível deliberar sobre o projeto em uma única reunião. A matéria não tinha sido objeto de análise pelas Câmaras Técnicas do Conselho, o que para Bahia (2006, p. 2-3) evidenciava o cunho eminentemente político da decisão a ser tomada. O CNRH defendia sua competência para deliberar sobre o projeto, amparado pela Lei n. 9.433/97, art. 35, III. Também foi divulgada a realização de nove audiências públicas ${ }^{7}$ com início em 06/12/2004, com o objetivo de apresentar o EIA/RIMA à sociedade.

Diante desses fatos, novas ações judiciais foram propostas com objetivo de impedir a deliberação do CNRH sobre o Projeto. Também em face dessas irregularidades (agendamento de audiências e da reunião do CNRH), o Ministério Público Federal e o Ministério Público do Distrito Federal impetraram, em novembro de 2004, um mandado de segurança preventivo contra o ato da presidência do $\mathrm{CNRH}$, requerendo, em liminar, a suspensão das reuniões e, portanto, da deliberação sobre o projeto.

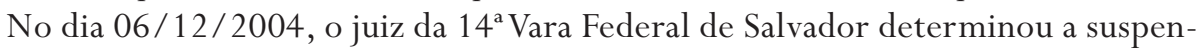
são das nove audiências públicas e do licenciamento ambiental e de qualquer procedimento de contratação por meio de licitação ou qualquer outro meio que objetivasse a implantação do Projeto. Em decorrência do embargo judicial, as audiências públicas não foram realizadas. Também em 06/12/2004, o juiz da $3^{\text {a }}$ Vara Federal de Sergipe ordenou: a) suspensão imediata do processo de licenciamento ambiental; b) abstenção da ANA de expedir a outorga do direito de uso das águas do São Francisco; c) imposição ao Ministério da Integração Nacional e à União Federal da obrigação de não fazer a licitação, declarando nula a já existente (BAHIA, 2006, p. 2-3).

Todavia, nova decisão judicial suspendeu as decisões anteriores e uma nova rodada de audiências públicas foi divulgada pelo Ibama (BONI, 2005, p. 4). ${ }^{8}$ A primeira 
delas, a de Fortaleza (CE), foi programada para poucos dias após a divulgação das datas das novas audiências $(15 / 01 / 2005)$. Também no início de janeiro de 2005, o CNRH designou nova reunião para 17/01/2005, cuja pauta era a deliberação sobre o Projeto (BAHIA, 2006, p. 3-4; ALENCAR, 2005, p. 6).

Entidades e órgãos de defesa do meio ambiente e dos interesses difusos e coletivos ingressaram com nova ação judicial no dia 05/01/2005, contra o Ibama, a União e a ANA, apontando a ilegalidade do Projeto, assim como as diversas irregularidades presentes no EIA/RIMA. Postularam, liminarmente, a invalidação das audiências designadas; a suspensão do procedimento de licenciamento ambiental e impedir a União de praticar qualquer ato tendente a concretizar o Projeto de Integração da Bacia do São Francisco (BAHIA, 2006, p. 4-5).

Dessa vez, todas as liminares foram negadas e o CNRH aprovou o Projeto de Transposição do rio São Francisco na reunião ocorrida dia 17/01/2005 e iniciou a rodada de audiências públicas programadas.

Por meio da Reclamação n. 3.074, processada no Supremo Tribunal Federal (STF), admitiu-se o ingresso da União no polo passivo e a competência originária do STF em todos os processos em que litigam Estados membros ou órgãos seus contra a União ou autarquia federal acerca do Projeto de Transposição. Por consequência, todas as ações em trâmite, tendo como objeto o projeto ou seu licenciamento, foram remetidas ao STF.

Com as ações judiciais ainda em curso no STF, o Ibama concedeu a Licença Ambiental Prévia n. 200/2005, em 29/05/2005, ao Ministério da Integração Nacional. Irresignadas diversas entidades recorreram novamente ao Judiciário.

No momento em que o STF avocou a competência, estavam tramitando vários processos contra a transposição, em diversos órgãos do Poder Judiciário, em vários Estados da Federação. A partir deste momento, todos foram encaminhados e seguem tramitando no STF (em dez/2014).

\subsection{As raZões, AS CONTraRraZÕeS E A DECISÃo liminar}

Segundo o Ministro Sepúlveda Pertence na decisão liminar (ACO 876, 2006, p. 14-16), prolatada em 18/12/2006, em síntese, os argumentos utilizados nas ações judiciais em trâmite e avocadas pelo STF visavam interromper o licenciamento ambiental e cassar a licença ambiental prévia 200/2005 e, por fim, impedir a execução do Projeto de Transposição ante os seguintes argumentos: a) existir falhas e omissões relevantes no EIA/RIMA, principalmente por não ter considerado os impactos ambientais, sociais e econômicos à parte mineira ${ }^{9}$ e baiana da bacia; b) não terem sido contempladas todas as alternativas tecnológicas e de localização do projeto, conforme prescrito no art. $5^{\circ}$, da Res. Conama n. 01/86; c) desconsiderar a Região do Alto e Médio São Francisco na área de influência direta do empreendimento; d) haver imprecisões técnicas quanto aos recursos hídricos da bacia, aproveitamento hidrelétrico e propostas de sistemas 
hidrossanitários; e) não ter sido cumprida a exigência de acompanhamento da certidão dos municípios atingidos pelo projeto; f) faltar a autorização do Congresso Nacional para a realização do projeto, pois há aproveitamento de recursos hídricos em terras indígenas, de acordo com o art. 231, § $3^{\circ}$, da CF/88; g) desconsiderar o Plano Decenal da Bacia (2004-2013); h) desrespeitar a Política Nacional de Recursos Hídricos; i) inviabilizar a realização das audiências públicas ante o curto lapso temporal entre a designação da data e sua efetiva execução, além da distância considerável dos locais onde se efetuariam as audiências das pessoas diretamente interessadas; j) vícios na aprovação da Resolução n. 411 emitida pela ANA ante a ausência da manifestação da Câmara Técnica; k) concessão da licença ambiental prévia 200/2005, apesar das falhas e das omissões apresentadas pelo EIA/RIMA e sem ser oportunizada a efetiva participação popular.

A parte contrária (Ibama, Ministério da Integração Nacional e a União), segundo o Ministro Sepúlveda Pertence (ACO 876, 2006, p. 16), na decisão liminar, em apertada síntese, alegava: a) o cumprimento às determinações legais; b) a realização das audiências públicas e a concessão da licença ambiental prévia não significam a conclusão do licenciamento nem mesmo o início das obras e, portanto, novos e outros esclarecimentos, bem como eventuais necessárias complementações do EIA/RIMA poderiam decorrer das indagações colhidas nas audiências; c) a concessão da licença prévia não provoca nenhum dano ao ambiente, pois não foram iniciadas as obras físicas do projeto; d) quanto às irregularidades nas licitações e contratações referentes às obras, aduziu a União que o Ministério da Integração Nacional tão somente divulgou o primeiro edital com o intuito de contratar empresa especializada para prestar apoio técnico ao Ministério da Integração visando à obtenção das licenças ambientais; e) a ilegitimidade ativa de algumas das entidades autoras.

No julgamento da liminar (18/12/2006), o Ministro Sepúlveda Pertence considerou sem legitimidade diversas entidades autoras de ações judiciais. ${ }^{10}$ Deste modo, por carência de legitimação ativa, o Ministro julgou extintas sem julgamento de mérito (art. 267, VI, do CPC) as seguintes ações: ACO 871; AC 981; ACO 869 (ACO 876, 2006, p. 18-23).

O Tribunal Pleno do STF, por maioria, manteve a decisão considerando as entidades sem legitimidade processual (19/12/2009). Durante o ano de 2010, diversas entidades e órgãos peticionaram ao STF pedindo a realização de audiência pública e o prosseguimento do feito.

As ACO 820, 872, 873 e 876 não foram extintas em decorrência da legitimidade ativa dos demais litisconsortes. E, assim, mantiveram curso com o julgamento da liminar as seguintes ações: ACO 820; ACO 876; ACO 857; ACO 858; ACO 872; ACO 873; ACO 870; ACO 886 (decisão da ACO 876, 2006, p. 18-23). Irresignadas, as partes consideradas sem legitimidade processual recorreram da decisão.

No julgamento da liminar, o Ministro destacou também que a solução da controvérsia versava em torno da questão: para conceder a licença prévia, é exigível somente o 
EIA/RIMA ou também sua aprovação? Se necessária a aprovação, todas as discussões sobre os estudos devem estar encerradas antes de ser deferida a licença prévia.

O Ministro Sepúlveda Pertence considerou que, para a concessão da licença prévia, bastava que os estudos requisitados pelo Ibama, principalmente no pertinente à viabilidade ambiental do projeto, mormente à sua localização e concepção fossem considerados "satisfatórios". Segundo o Ministro, os demais estudos somente são necessários para obter a licença de instalação e de operação, pois antes da concessão delas não serão realizadas obras físicas.

Considerou também ter o EIA/RIMA cumprido com todas as exigências legais, em especial, quanto aos requisitos prescritos pela Resolução Conama n. 01/86, em seu art. $5^{\circ}$. Afirmou: "foram preenchidos, ao menos sob o prisma formal, os requisitos mínimos exigidos pela legislação para apresentação do EIA/RIMA”. E ainda: “os vícios e as falhas acaso detectados no seu conteúdo poderão e deverão ser corrigidos no decorrer do processo de licenciamento ambiental, certo que sua eventual existência não significa, necessariamente, frustração do princípio da participação pública” (ACO 876, 2006, p. 46).

O Ministro destaca ainda ter o Ibama concluído que os alegados vícios de conteúdo do EIA/RIMA não foram suficientes para impedir a concessão por aquele órgão da licença prévia 200/2005, quando foram especificadas seis condicionantes gerais e trinta e uma específicas, as quais constituem pressupostos de eficácia da licença prévia e somente após o atendimento de todas e ocorrência das audiências públicas, poderá o órgão ambiental federal autorizar a realização das obras, concedendo a licença de instalação. Quanto à inexistência das certidões das prefeituras municipais, ele entendeu que elas eram necessárias para o licenciamento ambiental e não especificadamente no momento da apresentação do EIA/RIMA e, como foram apresentadas posteriormente, mas em tempo, considerou sanada a irregularidade. Compreendeu ter o Ibama cumprido a legislação e os prazos legalmente prescritos quando designou as audiências públicas e o cancelamento não impediria a concessão da licença prévia. Isso "implicaria a punição do empreendedor, quando é certo que não se lhe pode imputar culpa pelos fatos”, conforme manifestação do Ministro Sepúlveda (ACO 876, 2006, p. 29-50).

Quanto à suposta ilegalidade da outorga de direito do uso das águas e do certificado de avaliação da sustentabilidade hídrica emitidas pela ANA, o Ministro considerou serem conclusivos os argumentos apresentados por esta última.

Com base nesses argumentos e fatos, o Ministro Sepúlveda Pertence cassou, em 18/12/2006, todas as liminares que suspendiam o processo de licenciamento ambiental, em específico a licença prévia concedida pelo Ibama. A partir desta decisão liminar, o Ministério da Integração Nacional deu continuidade ao pedido de licenciamento e a licença prévia retificatória foi concedida em 29/12/2006 e a licença de instalação em 23/03/2007 (ACO 876, 2006, p. 46-50). 
Convém ainda destacar que, na véspera da concessão da licença de instalação 438/2007, o Procurador do Ministério Público Federal do Distrito Federal, Francisco Guilherme Vollstedt Bastos recomendou ao presidente do Ibama não expedir a referida licença até que os projetos executivos fossem concluídos e as audiências públicas (para debater os estudos ambientais complementares) fossem realizadas (site do MPF). Ainda antes de ser conferida a licença de instalação, o TCU, em 03/11/2006, com publicação no D.O.U. em 06/11/2006, por meio do Acórdão n. 2.017/2006, recomendou ao Ministério da Integração Nacional não iniciar as obras ante a ausência de segurança jurídica, pois não há decisão final sobre o Projeto, já que a liminar concedida pelo Ministro Sepúlveda Pertence poderia ser cassada pelo tribunal pleno do STF. O TCU constatou 20 irregularidades nas contratações e licitações, conforme anteriormente mencionado.

A licença de instalação foi concedida sem a realização das audiências públicas recomendadas pelo Ministro Sepúlveda Pertence. Dispensável mencionar que as audiências são necessárias para dar publicidade aos estudos do projeto que não tinham sido apresentados quando da concessão da licença prévia. Seria a oportunidade para a sociedade participar, efetivando o direito-dever constitucional à participação (art. 225 da CF/ 88). Com a licença de instalação em mãos, o Ministério da Integração Nacional deu início às obras da transposição.

Ante a não realização das audiências públicas, inexistência dos estudos conclusivos e controvérsia nos estudos apresentados, o Procurador-Geral da República, Antônio Fernando Souza, em fevereiro de 2007, ajuizou agravo regimental no STF, pedindo a suspensão da licença ambiental de instalação e cassação da licença prévia, além de solicitar que o Congresso Nacional e as populações indígenas fossem consultados quanto ao projeto, conforme informações disponibilizadas no site da Procuradoria-Geral da República (POMPEU, 2007).

Em que pese o STF ter avocado todos os processos, no dia 10/12/2007, o Tribunal Regional Federal da $1^{\text {a }}$ Região, em grau de recurso, acatou o pedido do Ministério Público Federal e suspendeu liminarmente as obras do Projeto de Integração do Rio São Francisco. Para o MPF, o projeto não poderia ter sido aprovado pelo $\mathrm{CNRH}$ por três razões: a) o aporte hídrico pleiteado para a transposição é alvo de um procedimento administrativo no Comitê de Bacia Hidrográfica do rio São Francisco, o qual ainda não tinha sido analisado; b) o projeto viola o Plano de Recursos Hídricos por visar ao aproveitamento econômico dos usos da água; c) o projeto viola também os princípios da gestão descentralizada da água e da participação popular instituído pela Política Nacional de Recursos Hídricos (Lei n. 9.433/97).

Cabe destacar que a Diretoria do Comitê da Bacia Hidrográfica do rio São Francisco, reunida em Brasília, no dia 03/07/2007, reiterou sua resistência à transposição e publicou a seguinte nota: 
A Diretoria Colegiada do Comitê da Bacia Hidrográfica do rio São Francisco, reunida em Brasília, reitera a sua posição contrária ao Projeto de Transposição e lamenta que o Governo Federal esteja dando inicio às obras sem aguardar o exame de mérito das diversas ações que tramitam no Supremo Tribunal Federal além de atropelar o diálogo prometido pelo próprio Presidente da República e que foi interrompido pela ânsia de executar o projeto a qualquer custo, inclusive valendo-se do Exército Brasileiro para criar um fato consumado quanto ao início da transposição. A direção do CBHSF aproveita a oportunidade para manifestar, dentro da lei, sua solidariedade à população e às entidades da sociedade civil que estão acampadas em Cabrobó, como último gesto de pleno exercício da cidadania que resta àqueles que discordam do projeto e cujos argumentos e reivindicações não foram, até o momento, devidamente considerados pelo Governo Federal.

Não obstante, em sessão plenária, no dia 19/12/2007, o STF por seis votos contra três revogou a liminar concedida pelo TRF e julgou improcedente o agravo ajuizado pelo Procurador-Geral da República, assim como negou o provimento dos agravos regimentais interpostos pelas partes "sem legitimidade" processual, acatando o pedido da Advocacia-Geral da União (informações disponíveis no site do Senado Federal).

Embora todas as liminares tenham sido cassadas pelo Ministro Sepúlveda Pertence, até o momento da publicação deste artigo (dez/2014) não há uma "decisão jurídica final” acerca da lide. Diversos processos avocados pelo STF ainda tramitam com o escopo de obstaculizar a execução da transposição (Reclamação 3883, ACO 876, ACO 872, ACO 1052, ACO 873, ACO 820, ACO 870).

A partir da análise dos fatos apresentados, sobressai a unívoca decisão política de executar o projeto. E, mesmo sem decisão judicial transitada em julgado, torna-se difícil acreditar que a decisão liminar vai ser revertida. As obras da transposição estão 69,2\% concluídas e o prazo de conclusão apresentado é 2015, conforme informa o Ministério da Integração Nacional em seu site. Diversos processos tramitam no STF e se, porventura, a decisão judicial final for de encontro à liminar, será tarde, pois muito dinheiro público já terá sido gasto, o ambiente restará degradado em meio ao canteiro de obras e boa parte da população desiludida com os Poderes Executivo e Judiciário (STF).

\section{Os imbróglios JURÍdicos da transposição do Rio SÃo Francisco}

A transposição do rio São Francisco está marcada, em especial, por três grandes imbróglios jurídicos: o desrespeito a importantes preceitos das normas vigentes: 1) Plano Decenal da Bacia do rio São Francisco (2004-2013); 2) Política Nacional de Recursos 
Hídricos (Lei n. 9.433/97); e 3) da legislação ambiental brasileira, em especial, daquela que versa sobre o licenciamento ambiental e a adoção dos princípios da prevenção, precaução e participação, este também consagrado no texto constitucional como direito-dever.

\section{I Derrogando o Plano Decenal de Recursos Hídricos da Bacia do São} Francisco e a Política Nacional de Recursos Hídricos (2004-2013)

O Plano Decenal de Recursos Hídricos da Bacia do São Francisco (MEDEIROS, 2007) foi elaborado sob a coordenação da ANA e financiado pelo Banco Mundial. Para sua confecção, foi criado um Grupo Técnico de Trabalho do qual fizeram parte representantes da ANA, da Companhia de Desenvolvimento do Vale do São Francisco (CODEVASF) e dos Estados de Minas Gerais, Goiás, Bahia, Pernambuco, Sergipe e Alagoas e do Distrito Federal e colaboraram representantes da Companhia Energética do Estado de Minas Gerais (CEMIG), da Companhia Hidroelétrica do São Francisco (CHESF) e da Coordenação do Programa de Revitalização do Governo Federal. Também participaram na elaboração do Plano as Câmaras Técnicas de Planos e Programas e de Outorga e Cobrança do Comitê da Bacia Hidrográfica do Rio São Francisco. Foram ouvidos representantes dos Ministérios do Meio Ambiente, da Integração Nacional, da Agricultura, dos Transportes, entre outros, além de órgãos gestores dos recursos hídricos dos Estados, dos usuários e dos representantes da sociedade civil; consultores nacionais (COMITÊ DA BACIA HIDROGRÁFICA DO RIO SÃO FRANCISCO, 2004, p. 13).

Foram realizados encontros públicos para debater o Plano e sua metodologia. ${ }^{11}$ Na elaboração do Plano, serviram de subsídios estudos já prontos sobre a bacia, sendo os principais: Diagnóstico Analítico da Bacia, de maio de 2003, e o Programa de Ações Estratégicas, de dezembro de 2003, ambos financiados pela ANA/GEF/PNUMA/ OEA, conhecido como Projeto GEF São Francisco e, ainda, o Documento de Referência do Plano Nacional de Recursos Hídricos, de novembro de 2003 (COMITÊ DA BACIA HIDROGRÁFICA DO RIO SÃO FRANCISCO, 2004, p. 18).

A versão preliminar do plano foi aprovada na III Reunião Plenária do Comitê ocorrida em Juazeiro (BA), no período de 28 a 30/07/2004. Em face do pedido de vista do Secretário Nacional de Recursos Hídricos quanto à Proposta de Deliberação que definia limites, prioridades e critérios de alocação e outorga para usos externos à bacia, houve a necessidade de convocar uma nova reunião para o Comitê deliberar sobre a matéria (outorga), ocorrida posteriormente, em Salvador (BA), no dia 27/10/2004, quando foi homologada a Deliberação n. 18, de 27/10/2004. O Plano Decenal foi aprovado em 29/07/2004 por meio da Deliberação CBHSF n. 07 (COMITÊ DA BACIA HIDROGRÁFICA DO RIO SÃO FRANCISCO, 2004, p. 7-8).

A Deliberação do CBHSF n. 18, de 27/10/2004, tornou vigente o seguinte conteúdo ${ }^{12}$ : 
Art. $3^{\circ}$ - A concessão de outorga para uso externo à bacia hidrográfica do rio São Francisco fica restrita exclusivamente para consumo humano e dessedentação animal, atendidos os seguintes critérios (grifo nosso):

I - os atendimentos de pedidos de outorga dependem da existência de disponibilidade de água no ponto de captação, baseada na locação espacial estabelecida neste plano, e deverá considerar os resultados dos estudos de compatibilização entre os usos humanos e animal e a proteção da biodiversidade;

II - os valores definidos devem ser compatibilizados com valores médios de consumo humano reconhecidos internacionalmente como adequados para as características das bacias hidrográficas receptoras, tendo por base as condições de uso racional e eficiente das águas;

III - clara comprovação de indisponibilidade hídrica local para atendimento da demanda apresentada e da inviabilidade econômica e/ ou técnica de soluções nas bacias hidrográficas receptoras; (grifo nosso)

De encontro a esta deliberação, uma "brecha" na concessão da outorga hídrica definitiva ${ }^{13}$ pela Agência Nacional de Águas, em 22/09/2005, por meio da Resolução ANA 411, manteve acesas as dúvidas e coloca em pauta as intenções do projeto:

Art. $1^{\circ}$ Outorgar ao Ministério da Integração Nacional o direito de uso de recursos hídricos do Rio São Francisco, para a execução do Projeto de Integração do São Francisco com as Bacias Hidrográficas do Nordeste Setentrional, nas seguintes condições:

IV - excepcionalmente, será permitida a captação da vazão máxima diária de 114 $\mathrm{m}^{3} / \mathrm{s}$ e instantânea de $127 \mathrm{~m}^{3} / \mathrm{s}$, quando o nível de água do Reservatório de Sobradinho estiver acima do menor valor entre:

a) nível correspondente ao armazenamento de 94\% do volume útil; e

b) nível correspondente ao volume de espera para o controle de cheias;

Parágrafo único. Enquanto a demanda real for inferior a $26,4 \mathrm{~m}^{3} / \mathrm{s}$, o empreendimento poderá atender, com essa vazão, o uso múltiplo dos recursos hídricos na região receptora.

A ANA expediu em 22/09/2005, com publicação no D.O.U. n. 185, em 26/09/2005, p. 89, o Certificado de Avaliação da Sustentabilidade da Obra Hídrica $(\mathrm{CERTOH})$ para o Projeto de Integração do rio São Francisco. E, de acordo com Boni (2005, p. especial 4), no dia seguinte ao da emissão da outorga, a ANA emitiu uma nota técnica declarando que "uma vazão média diária de $87,9 \mathrm{~m}^{3} / \mathrm{s}$ referente a outros usos da água pode ser bombeada eventualmente”. A ANA em nenhum momento esclareceu o que é uma "situação excepcional” e quais seriam os "outros usos". 
Assim, a utilização da água poderá beneficiar usos que não foram elencados como prioritários pelo Plano Decenal, contrariando a Lei n. 9.433/97 (arts. 12 e 13) e a Resolução CNRH n. 16/2001 (art. $7^{\circ}, \S 3^{\circ}$ ). Estes dispositivos legais determinam que toda outorga estará condicionada às prioridades de uso estabelecidas nos planos de recursos hídricos.

O Plano Decenal do CBHSF prescreve como usos prioritários: a) uso interno (dentro da bacia), em casos de escassez, para o consumo humano e a dessedentação de animais; b) uso para insumo produtivo restrito e exclusivo para usos internos da bacia. Além de estabelecer os usos prioritários e demais elementos da gestão hídrica da bacia do rio São Francisco, “o Plano Decenal estabelece que somente $360 \mathrm{~m}^{3} / \mathrm{s}$ podem ser alocados (outorgados), dos quais 335 já foram. Sobram então $25 \mathrm{~m}^{3} / \mathrm{s}$ para utilização atual e futura de usos múltiplos, sendo prioritários os da bacia” (BAHIA, 2006, p. 12).

A transposição infringe o Plano Decenal, pois requereria em 2013, no mínimo, uma vazão continuada de $26,4 \mathrm{~m}^{3} / \mathrm{s}$. A utilização desta vazão foi postergada para 2015 , em virtude do atraso no cronograma inicial das obras. Essa vazão, por si, extrapola os limites reais da vazão outorgável prevista no plano em $1,4 \mathrm{~m}^{3} / \mathrm{s}$. Não obstante, conforme a outorga, o Certificado de Avaliação da Sustentabilidade da Obra Hídrica e a Nota Técnica expedidos pela ANA podem ser necessários e concedidas vazões maiores: 65 $\mathrm{m}^{3} / \mathrm{s}, 87,9 \mathrm{~m}^{3} / \mathrm{s}$ e $127 \mathrm{~m}^{3} / \mathrm{s}$. Assim, a demanda hídrica da transposição (Eixo Norte e Eixo Leste) extrapola os níveis outorgáveis de água, infringindo o Plano Decenal, no pertinente aos usos prioritários e à sustentabilidade ambiental e viabilidade da obra.

Convém esclarecer que o Plano Decenal admite a concessão de água para usos externos (por exemplo, CE, RN, PB), todavia, visando ao consumo humano e à dessedentação animal, em caso de comprovada escassez e mediante clara comprovação da indisponibilidade hídrica local para o atendimento da demanda e indisponibilidade econômica e/ou técnica de soluções nas bacias receptoras (COMITÊ DA BACIA HIDROGRÁFICA DO RIO SÃO FRANCISCO, 2004, p. 147-148).

Ante a solicitação do Ministério da Integração Nacional, na elaboração do Plano, foi prognosticado o consumo hídrico futuro na bacia, com e sem a transposição, a partir da estimativa das taxas anuais de crescimento econômico e do consumo de água previsto para 2013 e 2025. Criaram-se três cenários de crescimento: tendencial, normativo e otimista, os quais preveem as seguintes taxas de crescimento econômico anual: $1,9 \%, 6,5 \%$ e $8,9 \%$, respectivamente (vide Tabela 1 ). 
TABELA 1 - O PROGNÓSTICO DOS CONSUMOS DA BACIA DO RIO SÃo Francisco PARA 2013

\begin{tabular}{|c|c|c|c|}
\hline CENÁRIOS & TAXA DE CRESCIMENTO & CONSUMO EFETIVO $2004\left(\mathrm{~m}^{3} / \mathrm{s}\right)$ & CONSUMO EFETIVO $2013\left(\mathrm{~m}^{3} / \mathrm{s}\right)$ \\
\hline $\begin{array}{r}\text { CENÁRIO } \\
\text { TENDENCIAL }\end{array}$ & $1,9 \%$ A.A. & \multirow{3}{*}{90,9} & 107,9 \\
\hline $\begin{array}{r}\text { CENÁRIO } \\
\text { NORMATIVO }\end{array}$ & $6,5 \%$ A.A. & & 134,9 SEM TRANSPOSIÇÃO \\
\hline $\begin{array}{l}\text { CENÁRIO } \\
\text { OTIMISTA }\end{array}$ & $8,9 \%$ A.A. & & 169,6 SEM TRANSPOSIC̣ÃO \\
\hline
\end{tabular}

Fonte: COMITÊ DA BACIA HIDROGRÁFICA DO RIO SÃO FRANCISCO, 2004, p. 133.

Os estudos que sedimentam o Plano estabelecem que o consumo efetivo de água na bacia, em 2004, era de $90,9 \mathrm{~m}^{3} / \mathrm{s}$, ou seja, dos $335 \mathrm{~m}^{3} / \mathrm{s}$ outorgados somente 90,9 $\mathrm{m}^{3} / \mathrm{s}$ estavam sendo efetivamente consumidos. Desse modo, os estudos do Plano prognosticaram o consumo futuro, com base no cenário normativo sobre o consumo atual efetivo. Assim sendo, dos atuais 90,9 m³ $/ \mathrm{s}$, ter-se-ia um consumo, em 2013, de 134,9 $\mathrm{m}^{3} / \mathrm{s}$ sem e de 160,4 $\mathrm{m}^{3} / \mathrm{s}$ com a transposição. O crescimento significativo no consumo hídrico, de acordo com o Plano, deve-se ao aumento das terras irrigadas e à instalação de projetos hidráulicos (COMITÊ DA BACIA HIDROGRÁFICA DO RIO SÃO FRANCISCO, 2004, p. 132-133).

Considerando o cenário para 2025, empregando-se a taxa de $8,9 \%$ a.a de crescimento (cenário otimista), e admitindo-se a instalação parcial, no mínimo 50\%, das áreas dos atuais projetos de irrigação, mas a transposição em sua plenitude: o consumo ficará em $262 \mathrm{~m}^{3} / \mathrm{s}$ sem transposição e $327 \mathrm{~m}^{3} / \mathrm{s}$ com a mesma. Assim, dos $360 \mathrm{~m}^{3} / \mathrm{s}$ outorgáveis restariam somente $33 \mathrm{~m}^{3} / \mathrm{s}$ para serem alocáveis nas próximas duas décadas, reputando-se desde já, que nem todos os projetos de irrigação poderão ser implantados (COMITÊ DA BACIA HIDROGRÁFICA DO RIO SÃO FRANCISCO, 2004, p. 132-133). Desse modo, os atuais problemas e conflitos seriam elevados ainda mais ante o pequeno espectro possível de outorga e o almejado desenvolvimento econômico poderá não ocorrer ou ficar estagnado e os danos ambientais já estarão concretizados.

As estimativas do Plano Decenal para o consumo em 2025 atestam que, "com a transposição o consumo em 2025 será de $327 \mathrm{~m}^{3} / \mathrm{s}$ e sem ela de $262 \mathrm{~m}^{3} / \mathrm{s}$ " (COMITÊ DA BACIA HIDROGRÁFICA DO RIO SÃO FRANCISCO, 2004, p. 133).

Contudo, importa ratificar que estes estudos foram realizados com base no atual consumo efetivo estimado em 90,9 m³ s (ano referência 2004), mas não se pode esquecer de que os valores já outorgados são superiores ao consumo efetivo, pois somam 
$335 \mathrm{~m}^{3} / \mathrm{s} \operatorname{dos} 360 \mathrm{~m}^{3} / \mathrm{s}$ alocáveis. Assim, com base nas outorgas concedidas, tem-se um saldo de disponibilidade hídrica de apenas $25 \mathrm{~m}^{3} / \mathrm{s}$ para o atendimento de novas outorgas, visto o projeto estabelecer um consumo mínimo de $26,4 \mathrm{~m}^{3} / \mathrm{s}$ e máximo de $127 \mathrm{~m}^{3} / \mathrm{s}$.

Destarte, a demanda supera a disponibilidade hídrica, acirrando-se ainda mais os conflitos na bacia. Impera salientar, antes de se apoiar no consumo efetivo e não no outorgado, que é indispensável suspender ou cancelar as outorgas ${ }^{14}$ que não utilizam a vazão concedida. E, neste sentido, entende-se ser necessária a motivação do ato pela administração pública, de acordo com as normas de Direito. A suspensão dessas outorgas não está isenta de recurso judicial, ou seja, não se pode prognosticar e autorizar um projeto de tal magnitude financeira, social e ambiental, alicerçando-se somente em prognósticos.

O Plano Decenal apresenta ainda outros dados: a) a retirada de $65 \mathrm{~m}^{3} / \mathrm{s}$ prevista para os Eixos Norte e Leste equivale a abrir mão da possibilidade de a bacia irrigar ${ }^{15}$ uma área aproximada de 150.000 a 200.000 hectares ou de geração de energia correspondente a esta vazão; b) priorizando-se a demanda do Projeto de Transposição em sua totalidade, o atendimento máximo das outorgas já concedidas seria de $85 \%$, não haveria saldo para outros usos e a concessão de novas outorgas dependeria exclusivamente de elevada redução nos valores já outorgados; c) há previsão de executar uma série de empreendimentos de grande porte na bacia, os quais não foram objeto de análises específicas nos estudos do plano. Alguns, inclusive, já têm suas obras iniciadas, enquanto outros estão ainda em fase de projeto. Dentre esses projetos, destacam-se: os canais do Sertão Pernambucano e Alagoano, cujo consumo total previsto está estimado em torno de $25 \mathrm{~m}^{3} / \mathrm{s}$, em 2013 e $41 \mathrm{~m}^{3} / \mathrm{s}$, em 2025, de acordo com o Plano Decenal (COMITÊ DA BACIA HIDROGRÁFICA DO RIO SÃO FRANCISCO, 2004, p. 131-146).

Na outorga, o CBHSF ainda não tinha regras estabelecidas acerca da alocação espacial (por Estado) ou por tipo de uso consuntivo ${ }^{16}$ e, a partir da outorga, a negociação entre os Estados membros que compõem a bacia se torna ainda mais complexa.

O Projeto busca apoio popular na inverídica assertiva de que os $26,4 \mathrm{~m}^{3} / \mathrm{s}$ visam ao consumo humano nas áreas mais afetadas pela seca, mas sólidos indícios demonstram que sua real intenção é disponibilizar água para irrigação, além de outros usos econômicos - promovendo o desenvolvimento econômico - não elencados pelo CBHSF como prioritários, tanto na alocação interna de água quanto na externa.

A propósito, a Sociedade Brasileira para o Progresso da Ciência (2004), no Relatório das Discussões sobre a transposição, considera que ela se desvia dos fins propostos - fornecimento de água para o consumo humano e animal - gerando preocupação quanto à partilha dos benefícios sociais do projeto:

Há diferenças fundamentais quanto à justificação dos dois eixos propostos.

O chamado Eixo Leste é proposto para o abastecimento humano das 
regiões mais secas de Pernambuco e da Paraíba e irrigação em sua maior parte na própria bacia do São Francisco. Por outro lado, o Eixo Norte, cujo objetivo é inequivocamente irrigação, baseia-se no princípio do aumento da sinergia dos grandes reservatórios do Ceará, Rio Grande do Norte e Paraíba. O projeto do Eixo Norte apresenta muitas incertezas no que se refere à viabilidade econômica e não há clareza quanto ao benefício social e à distribuição de renda que poderá ser gerada com o projeto. Além disso, em ambos os casos, a capacidade gerencial necessária para que as instituições públicas brasileiras venham a administrar o transporte de água em canais com centenas de quilômetros e a capacidade dos estados e da União de implementar as obras de modo a efetivamente utilizar a água, não condiz com o quadro atual, de dezenas de projetos inacabados e outros quase destruídos em função da má gestão. Portanto, seriam extremamente oportunas e prioritárias ações focadas na conclusão de inúmeras obras inacabadas existentes. (SOCIEDADE BRASILEIRA PARA O PROGRESSO DA CIÊNCIA, 2004, p. 12-13)

O próprio Plano Decenal destaca que "no conjunto da Bacia, a situação da disponibilidade hídrica é confortável, atendendo aos usos múltiplos atuais e futuros" (COMITÊ DA BACIA HIDROGRÁFICA DO RIO SÃO FRANCISCO, 2004, p. 102 103). Fontes (2007, p. 68), no mesmo sentido, declara ter o Comitê solicitado, por diversas vezes à ANA, a apresentação do balanço hídrico regional para ser possível constatar qual o real nível de escassez da bacia. Segundo o autor, apesar de a ANA prometer que o entregaria durante o processo de análise da outorga e emissão do Certificado de Avaliação da Sustentabilidade de Obra Hídrica, o balanço não foi entregue. Declara ainda o autor que a ANA concedeu a outorga somente com base nos dados fornecidos pelo Ministério da Integração Nacional, pois o levantamento do balanço hídrico foi divulgado em 2006, no Atlas do Nordeste - Abastecimento Urbano de Água.

O Centro de Recursos Ambientais da Bahia afirma que, se fossem executadas algumas ações como as previstas na transposição, por exemplo, construção de canais, cisternas e bombeamento para ativação dessa disponibilidade (superficial, 54,2 $\mathrm{m}^{3} / \mathrm{s}$, e subterrânea, $16,3 \mathrm{~m}^{3} / \mathrm{s}$ ), inclusive, com recursos inferiores aos investidos na transposição, a própria bacia receptora ( $\mathrm{CE}, \mathrm{RN}, \mathrm{PE}, \mathrm{PB})$ atenderia a demanda gerada pelo consumo: humano $\left(24 \mathrm{~m}^{3} / \mathrm{s}\right)$, industrial $\left(14 \mathrm{~m}^{3} / \mathrm{s}\right)$ e de boa parte do consumo da irrigação $\left(25,5 \mathrm{~m}^{3} / \mathrm{s}\right)$. Contabilizando a disponibilidade hídrica (água superficial e subterrânea) e a demanda integral (consumo urbano, industrial e irrigação), há um superávit de $7 \mathrm{~m}^{3} / \mathrm{s}\left(54,2 \mathrm{~m}^{3} / \mathrm{s}+16,3-24-14-25,5=+7 \mathrm{~m}^{3} / \mathrm{s}\right)$.

Desconsiderando a disponibilidade subterrânea e considerando a demanda integral, haveria um déficit de $9,3 \mathrm{~m}^{3} / \mathrm{s}\left(54,2 \mathrm{~m}^{3} / \mathrm{s}-24-14-25,5=-9,3 \mathrm{~m}^{3} / \mathrm{s}\right)$. Existem 
alternativas mais econômicas e sustentáveis, ou seja, não se justificaria executar a transposição, orçada em R \$ 8 bilhões.

Pesquisadores da Sociedade Brasileira para o Progresso da Ciência (2004), atores sociais e gestores hídricos afirmam que a transposição, em especial seu Eixo Norte, visa incrementar a produção agrícola e gerar um superávit hídrico, em especial no Ceará e no Rio Grande do Norte para uso em novos empreendimentos agrícolas e para a refinaria no Porto de Pecém (CE), visando ao desenvolvimento econômico da região (FONTES, 2007, p. 66-68). E, ainda que o número de pessoas beneficiadas com a execução do projeto seja significativamente menor que o divulgado pelo Governo, ou seja, menos de 5\% da população do Semiárido.

Suassuna (1999, p. 7), afirma: "está documentado que no Piauí (água subterrânea), Ceará e Rio Grande do Norte há disponibilidade local de água para irrigar mais de 250.000 hectares" - o projeto oficialmente tem como objetivo levar água visando ao consumo humano para os dois últimos Estados. Segundo o autor, "Há, também, possibilidade de aproveitamento das águas dos rios nordestinos", pois "as descargas anuais desses rios resultam em infiltração da ordem de 58 bilhões de $\mathrm{m}^{3}$ nos aquíferos. Utilizando $1 / 3$ desse volume seria possível abastecer toda a população nordestina, estimada em 47 milhões de pessoas: 200 litros por pessoa/dia. E o volume ainda seria suficiente para irrigar 2 milhões de hectares, a uma taxa de $7 \mathrm{mil} \mathrm{m}^{3}$ por hectare, ao ano". Suassuna (1999, p. 6) declara ainda: "Água existe e o que falta é traçar uma política capaz de utilizar melhor esse recurso"

Coelho (2005, p. especial 5) destaca: "o projeto baseia-se na tese falsa de que a escassez de água na região impede a sobrevivência em condições dignas das populações”. E ainda: "É falsa porque não responsabiliza a estrutura social, econômica e política pelo atraso e pela miséria no Nordeste", ou seja, a "indústria da seca". Consoante Vicente Barbosa Vieira, professor da UFCE (apud BONALUME, 2005, p. especial 2): "O Nordeste tem água suficiente para os próximos 20 a 30 anos, mas ela é mal distribuída”. Para o professor da UFRN, João Abner Guimarães Jr. (apud NORONHA, 2004, p. 1): "É chover no molhado. Esse projeto está querendo levar água para as regiões que já têm"; "nenhuma das cidades que sofriam com a seca no Rio Grande do Norte em 2003, teria seu problema resolvido com a transposição". O professor observa ainda que o Ceará, por exemplo, já conseguiu, com açudes e adutoras, armazenar uma quantidade de água mais do que suficiente para seus usos atuais. Guimarães Jr. (apud NORONHA, 2004 , p. 1) afirma também que o Estado usa somente $25 \%$ da sua disponibilidade hídrica potencial, e que "o problema da seca no Nordeste não é de quantidade, mas de democratização do acesso ao produto”.

No concernente à disponibilidade hídrica, o Plano Decenal destaca que, no conjunto, ela é suficiente, mas existem conflitos relevantes (já instalados) e de menor relevância (conflitos potenciais) (Mapa 1). De um modo geral, esses conflitos se estabelecem em decorrência da necessidade de atender os usos múltiplos: agricultura 
irrigada, geração de energia (instalação das barragens e operação de reservatórios), água para o abastecimento humano, diluição de efluentes urbanos, industriais e da mineração e a manutenção dos ecossistemas. A transposição potencializa ainda mais os conflitos já existentes, dificultando o desenvolvimento atual e futuro de diversas atividades relevantes para a bacia, principalmente a geração de energia elétrica: o rio São Francisco representa mais de $90 \%$ de todo o potencial hidrelétrico inventariado no Nordeste (do Maranhão a Bahia). Irrigação, navegação e pesca também sofreriam seus efeitos, além de tornar ainda mais precário o consumo humano e a manutenção do ecossistema do rio São Francisco.

\section{MAPA 1 - OS CONFLITOS HÍDRICOS NA BACIA HIDROGRÁFICA do Rio São Francisco}

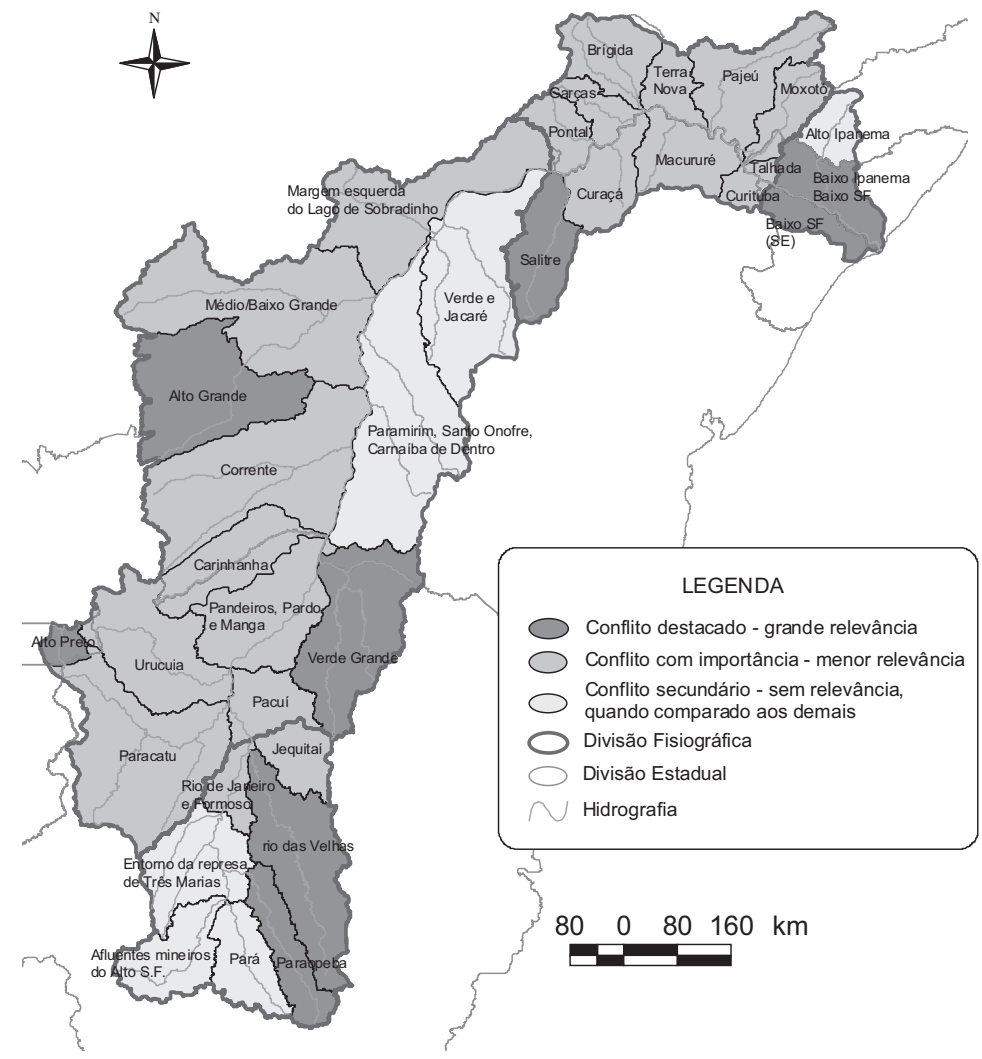

Fonte: COMITÊ DA BACIA HIDROGRÁFICA DO RIO SÃO FRANCISCO, 2004, p. 103. 
A propósito, o Plano (COMITÊ DA BACIA HIDROGRÁFICA DO RIO SÃO FRANCISCO, 2004) destaca que os conflitos atuais podem ser acirrados em função de diversos fatores, dentre os quais: a) crescimento da agricultura irrigada na bacia; b) retirada de água da bacia por transposição; c) revitalização da navegação fluvial; d) aumento da demanda energética; e) demandas ecológicas e as vazões remanescentes na foz.

Concedendo a outorga, a ANA não somente deixou de considerar aspectos técnicos relevantes; mas invalidou as decisões do Comitê; deixou de atender questões relacionadas à gestão da bacia, por exemplo, seus conflitos e a distribuição dos ônus sociais. Ao limitar-se à afirmativa de existir disponibilidade hídrica para a realização da obra, agravou ainda mais os conflitos regionais, principalmente entre Estados receptores e doadores, comprometendo usos presentes e futuros. Inviabilizaram igualmente usos consuntivos de relevância para a região, em especial, a geração de energia elétrica e a manutenção do ecossistema fluvial e costeiro associado à foz do rio.

O Plano Decenal e as decisões do Comitê restaram, em boa medida, sem eficácia a partir da decisão do STF, pois, em suma, a concessão da outorga para as obras da transposição infringe os seguintes artigos da PNRH: a) arts. $6^{\circ}$ e $7^{\circ}$, que adotam o Plano de Recursos Hídricos como o instrumento norteador da gestão hídrica na bacia, pois, apesar de sua existência e validade, ele não foi considerado pela ANA, MIN, MMA; b) art. 11, o qual estabelece que o regime de outorga de direitos de uso de recursos hídricos tem como objetivo assegurar o controle quantitativo e qualitativo dos usos da água e o efetivo exercício dos direitos de acesso à água, haja vista que a disponibilidade hídrica da bacia já está comprometida, inviabilizando a concessão de outorga para a transposição; c) art. 13, o qual prescreve que a outorga estará condicionada às prioridades de uso estabelecidas nos Planos de Recursos Hídricos, sendo prioritário, segundo o Plano Decenal, em caso de alocação externa de água, o consumo humano e a dessedentação de animais, se comprovada escassez e indisponibilidade de meios técnicos, e não a transposição, cujo escopo é alavancar a produção agrícola, piscicultura, entre outros usos econômicos; d) art. 38, III e seu parágrafo único, que atribuem a competência ao Comitê para aprovar o Plano de Recursos Hídricos e o papel de articulador das questões relacionadas aos recursos hídricos no âmbito da bacia.

Cumpre destacar que o CNRH ao usufruir da competência atribuída pela PNRH, qual seja: "deliberar sobre os projetos de aproveitamento de recursos hídricos que extrapolem o âmbito dos Estados em que serão implantados” (art. 35, III), invalidou boa parte das decisões do Comitê. Assim, numa perspectiva inicial, a decisão do CNRH é legal, pois amparada na lei, na competência que a PNRH lhe atribuiu (art. 35, III). Contudo, se for privilegiada a finalidade da lei e a análise das consequências da decisão, o caso poderia (poderá) ter outro desfecho. 


\subsection{A (IN)EFICÁCIA DO DIREITO AMBIENTAL BRASILEIRO}

\section{NA PROMOÇÃO DA SUSTENTABILIDADE}

O licenciamento ambiental é um dos instrumentos da Política Nacional de Meio Ambiente (Lei n. 6.938/81, art. $9^{\circ}$, IV) para a gestão ambiental e acautelamento de riscos. Ele tem como escopo principal a prevenção de danos, da poluição, da degradação ambiental e a melhoria e a recuperação da qualidade ambiental. Em decorrência do seu caráter acautelatório e do complexo conjunto de meios técnicos e científicos empregados, além dos estudos específicos requisitados, pode-se afirmar ser o licenciamento ambiental o principal instrumento de gestão ambiental no Brasil.

Todavia, no Brasil, por vezes, as práticas do licenciamento ambiental divergem das regras positivas na lei. As normas são descumpridas com o intuito de favorecer os interesses corporativos e privados, muitos deles no intuito de promover o desenvolvimento econômico.

No entanto, impera destacar que o licenciamento teoricamente propicia a participação popular, esta insculpida no texto constitucional como direito-dever da coletividade e também consagrada como princípio do direito ambiental (art. 225 da CF/88). A participação é relevante, pois a sociedade, como potencial vítima dos efeitos, em especial dos riscos, precisa opinar sobre os riscos a ela impostos e decidir se os aceita. Para Beck (1999), os riscos são fruto das decisões, e não se pode eliminar todos, de modo que a sociedade tem o direito e o dever de escolher a quais riscos quer se submeter, avaliando as questões envolvidas (sociais, econômicas, políticas, ambientais, éticas etc.). Não se pode olvidar de que a sociedade tem o direito-dever à participação!

A participação é direito-dever do cidadão, portanto, sua forma de materialização deveria ultrapassar os moldes do sistema representativo. Não se olvida que alguns instrumentos participativos proporcionam a "participação" do cidadão, como as audiências públicas, contudo, não possibilitam o "influenciar na decisão", pois não têm caráter deliberativo. E, ainda, na maioria das vezes, como no caso da transposição, a forma como são realizadas as audiências públicas impede a efetiva participação popular.

Sarlet (2012) leciona que o cenário jurídico-constitucional, especialmente naquilo em que está delineado para a tutela ecológica, encontra forte justificação no princípio (e dever) constitucional de solidariedade fundamental à proteção e promoção do ambiente nas relações entre particulares, o que no seu conjunto, e diante do quadro de risco existencial imposto pela degradação ecológica, impõe maior carga de responsabilidade no que diz com as ações e omissões dos particulares (pessoas naturais e jurídicas). E, ainda, a Constituição Federal de 1988, além de enunciar deveres de proteção estatais, em matéria ambiental, igualmente afirmou a responsabilidade dos particulares, pois, segundo o autor, a partir do art. 225 do texto constitucional, os particulares estão juridicamente vinculados ao dever de proteção ambiental, são 
atribuídos tanto direitos quanto deveres fundamentais em matéria ambiental, pois o "Estado estendeu seus tentáculos a todos os cidadãos, parceiros do pacto democrático, convencido de que só assim chegará à sustentabilidade ecológica” (SARLET, 2012, p. 13).

Para Hesse (1991, p.21), "direitos fundamentais não podem existir sem deveres". Canotilho (2004, p. 26), no mesmo sentido, leciona que é necessário deslocar o problema dos direitos fundamentais do campo dos direitos para o terreno dos deveres: "a necessidade de se ultrapassar a euforia do individualismo dos direitos fundamentais e de se radicar uma comunidade de responsabilidade de cidadãos e entes políticos perante os problemas ecológicos e ambientais”.

O dever se consolida na participação que, apesar de estar positivada e em alguns casos regulamentada, isto ainda não induz a necessária efetividade. Os cidadãos enfrentam obstáculos de ordem prática, política, jurídica e cultural. A propósito, Bobbio (1992), ao refletir acerca dos direitos, de um modo geral, constata que o problema de nosso tempo não é o de fundamentá-los, mas sim o de protegê-los.

É inegável que o cidadão brasileiro vem conquistando novos espaços, nova identidade e novos direitos: participação em audiências públicas (Resolução Conama n. 09/87, arts. $1^{\circ}$ e $2^{\circ}$ ); legitimidade para promover ação popular ambiental e anular ou impedir atos lesivos ao ambiente (Lei n. 4.717/65, art. $1^{\circ}, \S 1^{\circ}$ ); direito à informação de conteúdo ambiental existente em órgãos públicos (Lei n. $10.650 / 2003$, art. $2^{\circ}, \S 1^{\circ}$ ) e, principalmente, o direito/dever ao meio ambiente ecologicamente equilibrado ( $\mathrm{CF} / 88$, art. 225, caput). Mas na contemporaneidade, marcada por riscos globais, intergeracionais e transfronteiriços e pela incerteza, isso é insuficiente.

Ter ou tomar parte na decisão não é o mesmo que ter real influência na decisão e tampouco decidir, como poderia ser compreendido. Influir diretamente na decisão ou tomá-la é muito mais do que ter ou tomar parte. Portanto, participar das audiências públicas sem que estas tenham caráter deliberativo não confere real sentido à participação. Participar de conselhos e comitês cujos percentuais de participação sejam insignificantes tampouco induz participação, mas legitimação das decisões tomadas.

Marcondes e Andrade (2005) salientam que no Brasil, embora os mecanismos de participação tenham aumentado nos últimos anos, ainda não fazem diferença, mesmo que tenham avançado e se institucionalizado, é preciso que eles garantam algum poder de decisão, pois sem isso não há participação de verdade. Isso vale para os dias atuais, ainda que tenha se passado quase uma década.

$\mathrm{Na}$ aprovação da transposição, a participação pública, conforme exposto, restou fragilizada, distante de ser efetiva, mesmo assim, o Ministro Sepúlveda Pertence entendeu que não houve violação à lei, pois o fato de terem sido marcadas as audiências públicas denota o cumprimento à lei. Presenciar audiências públicas sem poder de deliberação, agendar audiências cujas práticas não objetivam cumprir a finalidade 
da lei etc. faz com que a concretização do direito-dever fique relegada para planos da inefetividade do texto constitucional e, sobretudo, o não respeito à finalidade da lei e se evidencie o desinteresse pelas consequências da decisão.

Acerca da viabilidade do projeto, as opiniões se dividem. Os principais defensores fazem parte do governo federal e de alguns Estados (CE, PB, PE, RN), ${ }^{17}$ empresários e fazendeiros da bacia receptora. O projeto é por eles defendido, em razão dos benefícios postulados: a) oferta de água para uma população estimada em 12 milhões; b) geração de mais de 240 mil empregos diretos e indiretos na área atingida e "em torno de 350 mil empregos nas regiões potencialmente beneficiadas em função de projetos irrigáveis em outras bacias - Região Metropolitana de Fortaleza e do Agreste Pernambucano"; c) viabilização da permanência de mais de 400 mil pessoas nas áreas rurais, evitando-se o êxodo rural; d) inserção de cerca de 186.000 hectares de novas terras agricultáveis por meio da irrigação (MINISTÉRIO DA INTEGRAÇÃO NACIONAL, 2004b, p. 82, 122-123; BRITO, 2005, p. A18).

Brito (na época coordenador-geral do Projeto de Transposição) chegava a defender o projeto com argumentos irresponsáveis: "o projeto não terá qualquer impacto ambiental negativo acima ou abaixo da barragem de Sobradinho" e ainda "o projeto é tecnicamente perfeito, socialmente justo e ambientalmente sustentável” (2005, p. A18). Igualmente, o coordenador-geral da obra da transposição, Macedo, a exemplo do coordenador do projeto, acena para a legalidade da obra e seus benefícios:

A decisão do Governo Federal de implantar o Projeto está baseada em dados, premissas e evidências que, pela sua clareza e consistência, não deixam dúvidas quanto a viabilidade e importância do empreendimento, não só para a região beneficiada como para o Nordeste e o país.

O Projeto foi exaustivamente discutido, resultado do amplo debate, significativa contribuição ao seu aperfeiçoamento.

Os impactos ambientais identificados são bem mais importantes e significativos no campo das vantagens, não tendo nenhum impacto negativo de relevância, tanto na bacia do São Francisco quanto nas bacias beneficiadas. Nenhum dos Projetos de Transposição feitos no mundo teve ou tem as condições ideais e os cuidados ambientais. (MACEDO, 2007, p. 75)

Os coordenadores do projeto e da obra, ao pronunciarem que estes cumprem as normas e não provocam impactos ambientais, evidenciam desconhecerem o RIMA da transposição, pois o próprio RIMA (MINISTÉRIO DA INTEGRAÇÃO NACIONAL, 2004b, p. 74-93) afirma que a transposição provoca 44 impactos, dos quais 23 (12 negativos e 11 positivos) são tidos como relevantes (vide Tabela 2 no final deste artigo).

$\mathrm{Na}$ verdade, quando o RIMA elenca os 44 “impactos" da transposição, ele está arrolando as 44 "consequências" auferidas na realização do EIA/RIMA. A maioria 
delas extrapola os níveis de tolerabilidade inerente à configuração técnico-jurídica de impacto ambiental (Resolução Conama n. 1/86, art. $1^{\circ}$ ). Assim, mais que impactos, muitas consequências previstas pelo RIMA engendram riscos à coletividade, bem como danos incomensuráveis: extinção de espécies, ruptura de relações sociocomunitárias etc. Insta ratificar que a terminologia adotada pelo RIMA, ora qualificando as consequências da transposição de impactos, ora de riscos, desrespeita as definições jurídicas (legais e doutrinárias). ${ }^{18}$

Embora o RIMA não apresente todos os efeitos reais da transposição, estes foram analisados por pesquisadores, experts, sociedade e exaustivamente discutidos, inclusive nas ações judiciais. Ademais, a SBPC e o Banco Mundial emitiram alerta sobre a viabilidade de outras alternativas e o baixo impacto da transposição na diminuição da pobreza etc. Restou nítido que o RIMA apresenta somente "alguns" resultados da transposição e que não há uma análise global acerca dos efeitos, pois as análises são compartimentadas. Mesmo assim, restou evidente o desrespeito aos princípios da prevenção e precaução e, portanto, ao direito ambiental brasileiro que os proclama como imprescindíveis para a persecução da sustentabilidade.

O RIMA não avaliou todas as possíveis consequências (impactos, danos e riscos), por exemplo, aquelas decorrentes da cunha salina; da salinização de açudes; dos efeitos sobre o lençol freático; da geração de efluentes; da competição e dos conflitos entre os Estados da bacia doadora e da receptora; da viabilidade econômica da operacionalização do sistema, entre outros (BAHIA, 2006, p. 20).

E também subdimensionou algumas consequências ao considerá-las "impactos irrelevantes" quando, na verdade, elas têm elevado potencial danoso ou de provocar riscos: redução da energia gerada e a perda de receitas municipais oriundas da compensação pelo uso dos potenciais hidrelétricos (com a transposição uma boa parte da água do rio São Francisco será direcionada aos canais e reservatórios desta, reduzindo a geração de energia elétrica e, com isso, as receitas da compensação). A queda na geração de energia elétrica afetará a operacionalização do sistema da transposição e outras atividades industriais e urbanas no Nordeste. Todavia, tanto a redução de energia elétrica quanto a compensação financeira foram consideradas impactos irrelevantes (MINISTÉRIO DA INTEGRAÇÃO NACIONAL, 2004b, p. 74).

O RIMA apresenta análises reducionistas, as quais desconsideram a ação recíproca e sinérgica das diversas consequências da execução do projeto. Os resultados da transposição, chamados pelo RIMA de impactos, foram analisados isoladamente, sem uma abordagem integrada e global. Ele não apresenta explicitamente os reais efeitos da transposição, pois foram subdimensionados em decorrência da análise compartimentada, quando não olvidados, pois nem sequer foram cogitados. A propósito, o RIMA considera "impactos positivos relevantes", por exemplo, a geração de empregos e renda durante a implantação. Ao mesmo tempo, considera "impactos negativos relevantes" a perda temporária (no início das obras) de empregos e renda por efeito 
das desapropriações, assim como afirma que a busca frustrada de emprego nas obras gerará tensões e riscos sociais. Ratifica-se, não há um balanço global acerca da geração ou perda de emprego durante a fase de execução do projeto, entre outras ambiguidades (HENKES, 2008).

Segundo informações disponibilizadas no site do Ministério da Integração Nacional, 38 programas ambientais foram elaborados para quando executados para prevenir, atenuar e corrigir os impactos ambientais gerados pela Transposição, monitorar as mudanças e promover a qualidade ambiental.

Por ora, serão examinadas, brevemente, as lacunas do RIMA, as quais foram objeto de inúmeras ações judiciais que demonstram a irresignação de diversos atores sociais, gestores de recursos hídricos, pesquisadores e da comunidade em geral com os propósitos governamentais e a aquiescência das instituições (Ibama, ANA, CNRH), bem como do Poder Judiciário (STF).

\subsection{As lacunas E IMPACTOS OLVIDADOS PELO RIMA}

A principal consequência da transposição olvidada pelo RIMA é o impacto que os custos da manutenção do sistema de operacionalização do projeto causarão à economia dos Estados e municípios atingidos pelo projeto, principalmente aqueles prejudicados com a diminuição das rendas oriundas da compensação financeira pelo aproveitamento do potencial hidrelétrico. Portanto, além de um grande problema, essa consequência representa mais que um impacto, um risco, o da não operacionalização do sistema pela inviabilidade financeira, pela sua insustentabilidade, além de diminuir as receitas para investimentos em educação, saúde etc. de inúmeros municípios. Além dos riscos e danos ambientais, como extinção de espécies da fauna e flora; poluição das águas; veiculação de vetores hídricos, elevação de óbitos e enfermidades; rupturas sociais causadas pelo deslocamento; sobrecarregamento da infraestrutura urbana e o agravamento da qualidade dos serviços públicos prestados (saúde, moradia, educação, entre outros) etc.

Acerca dos encargos da operacionalização do sistema, cabe salientar que, em conjunto, os Estados de Pernambuco, Ceará, Paraíba e Rio Grande do Norte serão obrigados a ratear os custos da operacionalização: Pernambuco pagará mais do triplo da conta que caberá ao Rio Grande do Norte em 2025, R \$ 42,8 milhões e R \$ 11,4 milhões, respectivamente (SALOMON, 2004, p. especial 3).

A imprevisão dos efeitos decorrentes da manutenção do sistema de operacionalização constitui grave falha, a qual impossibilita conhecer os reais impactos da obra na economia desses Estados e de alguns municípios. Outra consequência da transposição (considerada irrelevante pelo RIMA) é a redução das receitas de diversos municípios antes beneficiados com a compensação por utilizar os potenciais hidrelétricos. Com a transposição, será reduzida a produção de energia hidrelétrica em 2,4\%. Por conseguinte, reduzem-se as compensações e, assim, as receitas estatais e municipais, mas aumentam-se os encargos. 
Ainda cabe destacar que os Estados já se comprometeram com a cobrança de tarifa pelo uso da água e com a implantação da cobrança de tarifas pelos serviços de operação e manutenção do sistema operacional gerado pelas obras da transposição, pois a ANA condicionou a concessão do CERTOH à apresentação de garantias de gerenciamento futuro da obra, de acordo com Salomon (2004, p. especial 3). À época, o então Ministro da Integração Nacional, Ciro Gomes, afirmou que os menos favorecidos teriam água de graça. Contudo, a nota técnica da ANA que acompanhou a emissão do CERTOH, publicou "a conta” cabível a cada Estado, e acredita-se que todos, segundo a lógica mercantil, repassarão os custos para os consumidores e usuários.

Em reportagem publicada no Jornal Brasil de Fato (2005), com base nas informações prestadas pelo Governo, Alencar e Brasilino destacaram que o preço da água transposta seria de $\mathrm{R} \$ 0,11 \mathrm{o} \mathrm{m}^{3}$ (não incluindo a energia elétrica consumida pelas bombas para alocação das águas). Na época dessa divulgação, na região de Petrolina (PE), o metro cúbico custava $\mathrm{R} \$ 0,023$. A reportagem afirmava ainda que parte considerável da água transposta seria perdida por evaporação e infiltração: "cada hectare irrigado do projeto do governo federal será responsável pela perda de um volume de água que possibilitaria a irrigação de, no mínimo, dois ou três hectares à margem do São Francisco" (2005, p. 6).

O então coordenador geral do Projeto, Pedro Brito, em defesa incondicional à obra (2005, p. A18), declarou não ser a água da transposição do São Francisco a mais cara do mundo, como tinha sido afirmado, enfatizando que o valor a ser cobrado seria de “apenas" R \$ 0,11 por m³. Salientou ainda que, na Espanha, na Integração do rio Tajo com bacias de outras regiões espanholas, o custo da água era de $€ 0,15$ por $\mathrm{m}^{3}$.

Outra importante falha do RIMA (MINISTÉRIO DA INTEGRAÇÃO NACIONAL, 2004b) é ele "estranhamente" utilizar só o balanço hídrico da bacia receptora e não o de toda a bacia do São Francisco. Este possibilitaria uma visão geral da demanda e disponibilidade e das consequências no âmbito da bacia, decorrentes do desvio de água. $\mathrm{O}$ RIMA mencionou ainda ser a "vazão disponível” de $1.850 \mathrm{~m}^{3}$ / s e "somente" 3,5\% desta vazão seria utilizado nas obras da transposição. Esta afirmação é errônea, pois a "vazão disponível” não é $1.850 \mathrm{~m}^{3}$ /s, sendo esta a "disponibilidade hídrica total", a qual não se confunde com aquela; da disponibilidade hídrica total $\left(1.850 \mathrm{~m}^{3} / \mathrm{s}\right)$ deve ser subtraído o valor da "vazão de restrição" de $1.300 \mathrm{~m}^{3} / \mathrm{s}$ a ser mantida na foz do rio. Assim, a vazão disponível seria de $580 \mathrm{~m}^{3} / \mathrm{s}$ e não $1.850 \mathrm{~m}^{3} / \mathrm{s}$ alegados pelo RIMA. Portanto, o percentual requerido pela transposição passa dos 3,5\% para $11 \%$ da vazão do rio. Assim, a avaliação realizada torna-se ineficiente para prognosticar os reais impactos da transposição no âmbito da bacia.

E, nesse sentido, insta destacar outro equívoco cometido pelo RIMA, ao reduzir as análises dos "impactos" às áreas diretamente afetadas - faixa ao longo das estruturas do projeto com $5 \mathrm{~km}$ de largura para cada lado, totalizando $7.750 \mathrm{~km}^{2}$; e as áreas de influência direta - o conjunto de 86 municípios (CE, PB, RN, PE) atravessados pelos 
eixos de condução da água, num total de $67.000 \mathrm{~km}^{2}$. Juntas, somam menos de 75.000 $\mathrm{km}^{2}$, enquanto as desconsideradas, ou seja, as áreas de influência indireta, somam um total de $787.000 \mathrm{~km}^{2}$, dos quais $212.453 \mathrm{~km}^{2}$ correspondem às bacias exclusivamente receptoras (MINISTÉRIO DA INTEGRAÇÃO NACIONAL, 2004b, p. 54). Portanto, os estudos deveriam compreender a totalidade da bacia hidrográfica (correspondente a 8\% do território nacional), mas desconsideraram todo o curso do alto e médio São Francisco - situados antes do ponto de encontro com o Reservatório de Sobradinho.

O projeto apresenta uma demanda média de $63,5 \mathrm{~m}^{3} / \mathrm{s}-$ o que corresponde aritmeticamente à soma da demanda do consumo humano $\left(24 \mathrm{~m}^{3} / \mathrm{s}\right)$, industrial $\left(14 \mathrm{~m}^{3} / \mathrm{s}\right)$ e irrigação $\left(25,5 \mathrm{~m}^{3} / \mathrm{s}\right)$ - e máxima de $127 \mathrm{~m}^{3} / \mathrm{s}$. Justifica-se por disponibilizar água para o consumo humano e industrial, mas disponibilizará mais água para a irrigação do que para o consumo humano, ou seja, $25,5 \mathrm{~m}^{3} / \mathrm{s}$ contra $24 \mathrm{~m}^{3} / \mathrm{s}$, respectivamente. Assim, a afirmação de que ele visa beneficiar "as pessoas sedentas do Semiárido" é em parte inverídica, porque o escopo principal do Eixo Norte é incrementar as atividades econômicas e garantir um superávit hídrico nos Estados do Rio Grande do Norte e Ceará, enquanto se reconhece o déficit hídrico nas regiões beneficiadas pelo Eixo Leste. No entanto, isso não assegura que a água transposta por esse eixo estará à disposição dos habitantes, em restrição ao incremento dos usos econômicos.

Nesse sentido, a análise procedida pelo Centro de Estudos Ambientais da Bahia (2004, p. 30) destaca que diversos estudos científicos revelam o estágio de sustentabilidade hídrica de alguns Estados, concebidos pelo projeto de integração como futuros beneficiários do empreendimento. Por exemplo, o Estado do Ceará apresenta a maior infraestrutura hídrica do Semiárido, acumulando em torno de 18,2 bilhões de $\mathrm{m}^{3}$, em aproximadamente, oito mil açudes públicos e privados. Vale relembrar as afirmações de Fontes (2007, p. 66-68) sobre o superávit hídrico nos Estados do Rio Grande do Norte e Ceará que serão gerados pela transposição, viabilizando incrementar as exportações (frutas e camarão) pelo Porto de Pecém (CE). A bacia receptora tem autossuficiência hídrica para atender o consumo humano e industrial (38 $\mathrm{m}^{3} / \mathrm{s}$ ), bastando a ativação desta disponibilidade por meio de alternativas mais baratas e sustentáveis.

Acerca das alternativas ao Projeto, o Banco Mundial, a pedido do governo brasileiro, fez uma análise e entendeu que, antes da execução da transposição, alternativas com efeitos de curto prazo deveriam ser executadas, por exemplo, a construção de cisternas e reservatórios para água da chuva; dessalinização da água etc., como também concluir os projetos iniciados. O Relatório do Banco Mundial, disponível no site do Comitê (p. 4, 8-9), ressalta que o projeto terá baixo impacto na redução da pobreza e, igualmente, no alívio da seca:

O projeto proposto só afetaria uma pequena porcentagem da população do Nordeste que sofre de periódica falta de água. Uma abordagem 
programática e estratégica mostra que esta população pode ser alcançada de forma mais efetiva através da combinação de atividades direcionadas. Primeiro, a conclusão de projetos hídricos existentes com o objetivo de otimizar o uso de recursos hídricos disponíveis podem proporcionar resultados a curto prazo. [...]. Segundo, para cidades de porte médio, chama-se atenção para programas de sucesso de reservatórios de tamanho médio e o sistema de distribuição no Ceará, a implementação de uma grande rede de canos dos atuais reservatórios no Rio Grande de Norte, e iniciativas similares implementadas através do projeto PROÁGUA em muitos outros Estados do Nordeste. Estes sistemas estão fornecendo um confiável suprimento de água a várias cidades que lutaram contra a falta de água por muitos anos. Em terceiro lugar, suprimento de água para comunidades pobres e esparsas pode ser alcançado através de alternativas de baixo custo tais como cisternas, colheita da água da chuva, barragens subterrâneas, dessalinização, entre outras.

Contudo, o RIMA (MINISTÉRIO DA INTEGRAÇÃO NACIONAL, 2004b, p. 33 35) afirma que as alternativas à execução da transposição são: a) complementares em termos de público-alvo (construção de cisternas e poços); b) restritas em ocorrência espacial, quanto à qualidade da água e da distância (caso de água subterrânea e reuso do esgoto); c) limitadas em disponibilidade adicional (novos açudes); d) onerosas e tecnicamente menos eficientes (transposição do rio Tocantins e dessalinização de água do mar).

Apesar dessa afirmação, sabe-se que ações eficientes visando revitalizar a bacia, como a ativação da disponibilidade hídrica existente na bacia receptora e a construção de cisternas e poços para armazenamento de água são escolhas mais baratas e viáveis tecnicamente, além de serem ambientalmente sustentáveis e a sua execução mais rápida, de modo a resolver os problemas existentes antes, prevê-se que as obras da transposição estejam concluídas totalmente em 2025. Essas opções também amenizariam e reduziriam significativamente os impactos, danos e riscos causados à flora e fauna nativa, além dos abalos sociais, como rupturas das relações sociocomunitárias.

Até mesmo porque, apesar do elevado orçamento (cerca de R \$ 8 bilhões), a água transposta não chegará diretamente à casa de todos os nordestinos. Muitos deles somente terão acesso nos "chafarizes públicos, em cerca de 400 localidades urbanas, todas inseridas na área diretamente afetada, beneficiando aproximadamente 70 mil pessoas”, conforme o RIMA (MINISTÉRIO DA INTEGRAÇÃO NACIONAL, 2004b, p. 82). Desse modo, o problema da "falta de água” para a população local permanecerá, embora a disponibilidade hídrica local aumente. Ou seja, a oferta de água crescerá, mas não resolverá todos os problemas (de acesso à água) da população. Novamente, evidencia-se que o grande problema é a democratização do acesso e não a oferta de água. 
A propósito, segundo Villa (2005, p. A3), o principal dilema da região não é a falta de água, haja vista o índice pluviométrico ser razoável; a questão é como conservar e dar uso racional à água, ou seja, democratizar o acesso.

No mesmo sentido, Ab’Sáber (2005a, p. 98) enfatiza: "Nas discussões sobre a transposição das águas do São Francisco para o setor norte do Nordeste seco, existem alguns argumentos tão fantasiosos e mentirosos que merecem ser corrigidos”. Segundo o autor, o primeiro deles é a transposição resolver os grandes problemas sociais da região semiárida: "Trata-se de um argumento completamente infeliz". A água transposta não vai solucionar o problema, se outras políticas não forem conjuntamente implementadas.

De acordo com o Centro de Recursos Ambientais da Bahia (2004, p. 56), na análise dos impactos ambientais da transposição, o RIMA selecionou apenas 11 unidades de conservação das 123 existentes na bacia receptora, por estarem na área de intervenção direta do empreendimento, fato que pode subdimensionar as consequências causadas à área integral. Cinco espécies exógenas à bacia do rio São Francisco, sob influência, do empreendimento, já foram citadas como espécies com algum nível de risco de extinção: a pirapitinga (Brycon orthotaenia), a piabinha (Compsura heterura), a piabinha (Hemigrammus brevis), o mandi-açu (Duopalatinus emarginatus) e o niquim (Lophiosilurus alexandri). A propósito, destaca-se que a área indiretamente afetada é uma área do patrimônio histórico e arquitetônico com construções dos séculos XVII e XVIII, além das riquezas naturais, como grutas, lagoas e reservas florestais e sítios arqueológicos de valor inestimável que serão atingidos e provavelmente destruídos pela transposição (CENTRO DE RECURSOS AMBIENTAIS DA BAHIA, 2004, p. 40-59).

Inúmeros outros questionamentos acerca da sustentabilidade da obra são necessários. Ab'Sáber, em linhas gerais, destaca que pouco se pode adiantar a não ser a falta de conhecimentos sobre a dinâmica climática e a periodicidade do rio que vai perder água e dos rios intermitentes e sazonais que vão receber filetes de águas transpostas. O autor ressalta que um ponto obscuro da transposição é como evitar a grande evaporação da água por meio da caatinga, onde o índice de evaporação é o maior de todos e, ainda:

O risco final é que, atravessando acidentes geográficos consideráveis, como a elevação da escarpa sul da chapada de Araripe - com grande gasto de energia! - a Transposição acabe por significar apenas um canal tímido de água, de duvidosa validade econômica e interesse social de grande custo, e que acabaria por movimentar o mercado especulativo na terra e da política. No fim, tudo apareceria como o movimento de transformar todo o espaço em mercadoria. (AB'SÁBER, 2005a, p. 98)

Além dessas irregularidades e infrações, outras podem ser observadas: a) o descumprimento do Decreto Federal n. 4.024, o qual determina: as obras de infraestrutura hídrica da União devem obedecer a critérios de sustentabilidade operacional e 
hídrica, devidamente comprovados pela ANA; b) a necessária autorização do Congresso Nacional a teor dos arts. 49 e $231, \S 3^{\circ}$, da CF/88, pois as obras terão impacto em terras indígenas; c) solicitação formal da anuência prévia dos gestores das unidades de conservação, conforme exigência da legislação específica não observada. De acordo com o Professor Guimarães (apud NORONHA, 2004, p. 1), "uma auditoria isenta, com certeza, deveria revelar a inviabilidade do Projeto de Transposição e contestar a certificação da obra por parte da ANA”.

Villa (2005, p. A3) destaca que, de toda a discussão sobre o projeto, pelo menos uma é positiva, ou seja, é preciso fazer algo urgente pelo Semiárido. Contudo, o autor revela ser quase nula a presença do Governo Federal na região. E quando ele diz estar preocupado com a situação e querer acabar com a "indústria da seca", paradoxalmente busca alianças no Congresso Nacional com os representantes dessa "indústria”.

Anunciada como a solução para a seca do Semiárido e a mola propulsora do desenvolvimento, a transposição está gerando e gerará danos ambientais e sociais que não foram adequadamente contabilizados e considerados nas decisões. Se houver desenvolvimento, com certeza não será democrático e sustentável.

O próprio RIMA evidencia "uma parte” dos riscos e danos decorrentes da transposição, o que seria suficiente para a aplicação dos princípios da prevenção e da precaução. Não restam dúvidas acerca da prevalência dos princípios sobre as regras. Neste sentido, Dworkin, Alexy, Eros Grau, Celso Antônio Bandeira de Mello, entre outros.

\section{CONCLUSÃo}

Indubitavelmente, o Projeto da Transposição do rio São Francisco divide opiniões. A partir da realização da pesquisa, com base na análise de inúmeros documentos, estudos e depoimentos, constatou-se que a execução da transposição não resolverá o problema da "falta de água", embora a disponibilidade hídrica aumente no Semiárido Nordestino. O problema continuará sendo a democratização do acesso e não a oferta de água. Os problemas poderiam ser resolvidos com soluções alternativas de menor impacto ambiental e menor custo financeiro e social. O Programa de Revitalização do São Francisco, o "primo pobre" da transposição, é aceito pela comunidade local e considerado pela comunidade científica o mais viável, além de sustentável.

De fato, a economia da região pode se beneficiar com a obra e se desenvolver economicamente por meio da instalação de novos postos de trabalho, mas os resultados positivos deste desenvolvimento (econômico) não serão igualitários. Poucos se beneficiarão muito, por exemplo, com os pagamentos das desapropriações, das empreiteiras, fazendeiros etc. e muitos pouco receberão. Os danos e riscos ambientais atingirão as presentes e futuras gerações. Os estudos trazidos à baila demonstram como a obra, em especial no Eixo Norte, foi concebida para beneficiar o desenvolvimento econômico sem a devida preocupação com o desenvolvimento sustentável. 
O número acentuado de ações judiciais propostas visando suspender a concessão das licenças ambientais em razão das falhas e omissões relevantes no EIA/RIMA evidenciam a inaceitabilidade social do Projeto e também a desconsideração de preceitos legais da PNRH; do Plano Decenal; da CF/88, no que tange ao direito-dever ao meio ambiente ecologicamente equilibrado e à participação e, também dos princípios do direito ambiental, como o da participação, prevenção e precaução.

Cabe ainda salientar que o longo percurso judicial não findou, pois não há uma decisão transitada em julgado, mas o caminho até então percorrido é exemplificativo para ser afirmado que: a) a decisão jurídica final (STF) ratificará as anteriores; b) a execução da obra até o presente já causou danos e impactos ambientais (negativos), além dos sociais de significativa repercussão e gravidade, gerou riscos, além do descrédito na justiça e no Direito brasileiro; c) os riscos ambientais impostos à coletividade decorrentes da execução da obra são de alta magnitude, comprometendo, inclusive, a própria operacionalização e manutenção do sistema e demonstrando sua insustentabilidade, em que pese o RIMA tenha elencado somente 44 consequências; d) os imbróglios jurídicos evidenciam o esvaziamento da função delegada aos comitês de bacia pela PNRH e, isso, por consequência, gera o descrédito na gestão hídrica participativa; e) embora o direito ambiental brasileiro esteja munido de instrumentos aptos a promover o desenvolvimento sustentável, as práticas jurídicas têm demonstrado que o problema é sua efetividade e que há um grande hiato entre a lei e as práticas oficiais; f) o direito-dever à participação carece de um alto nível de concretização no direito brasileiro.

NOTAS

1 De acordo com Leite, a primeira foi a do Ouvidor Marcos Antônio de Macedo, em 1847 (LEITE, 2005, p. 7).

2 A se realizarem em: Sousa (PB), em 19/03/2001; Natal (RN), em 21/03/2001; Fortaleza (CE), em 23/03/2001; Aracaju (AL), em 26/03/2001; Penedo (AL), em 28/03/2001; Belo Horizonte (MG), em 30/03/2001; Salgueiro (PE), em 06/04/2001; Salvador (BA), em 09/04/2001 e Juazeiro (BA), em 10/04/2001 (HENKES, 2008).

3 Em 03/04/2001, o Centro de Recursos Ambientais (CRA), órgão executor da política ambiental baiana ingressou com uma ação civil pública contra o Ibama objetivando suspender as audiências públicas previstas no processo de licenciamento em face das irregularidades constatadas no EIA/RIMA. A ação foi julgada procedente e confirmada pelo Tribunal Regional Federal da $1^{\mathrm{a}}$ Região; 2) O Gambá (ONG ambientalista com atuação na Bahia) ingressou com outra ação civil pública contra o Ibama e a União. Em consequência da propositura dessas ações, as audiências públicas programadas para Aracaju (SE), Penedo (AL), Salvador (BA) e Juazeiro (BA) não foram realizadas. 
4 Consoante Leite (2005, p. 7), “Até 2003 [Lula] manteve uma atitude que foi interpretada como dúbia, ou de respeito pela ala ambiental do PT e pela Igreja, que se posicionaram contra o desvio”.

5 Segundo Suassuna (1999), todos os documentos existentes na CHESF sobre o Projeto Sobradinho fazem referência a uma vazão mínima garantida do rio. O conceito dessa vazão mínima garantida é que, sem qualquer barragem, em outubro de 1955, o rio São Francisco registrou a menor vazão jamais lida em Juazeiro/Petrolina, ou seja, 595 m³/s. Existindo Três Marias e Sobradinho, é possível garantir que, ocorrendo uma estiagem semelhante à da década de 1950 e se reproduzindo vazão semelhante à daquele ano, Sobradinho liberará, no mínimo, $2.060 \mathrm{~m}^{3} / \mathrm{s}$ para alimentar as usinas existentes a jusante (Itaparica, Moxotó, Paulo Afonso I, II, III e IV, e Xingó). Em anos de cheia, a média é bem maior do que os $2.060 \mathrm{~m}^{3} / \mathrm{s}$, podendo ocorrer, como em 1945, 1949 e 1979 , uma média superior a $4.500 \mathrm{~m}^{3} / \mathrm{s}$. Contudo, de acordo com o autor, serão sempre registradas vazões maiores que $2.060 \mathrm{~m}^{3} / \mathrm{s}$, pois este é o mínimo garantido.

6 Para uma análise detalhada dos entraves, consultar Henkes (2008).

7 A se realizarem em Salvador (BA), Belo Horizonte (MG), Juazeiro (BA), Penedo (AL), Aracaju (SE), Fortaleza (CE), Natal (RN), Sousa (PB) e Salgueiro (PE).

8 As audiências públicas deveriam ocorrer em: Fortaleza (CE), Natal (RN), Sousa (PB) e Salgueiro (PE), Belo Horizonte (MG), Salvador (BA), Aracaju (SE) e Maceió (AL). Apenas as audiências de Fortaleza (CE), Natal (RN), Sousa (PB) e Salgueiro (PE) foram realizadas; as de Belo Horizonte (MG), Salvador (BA), Aracaju (SE), Maceió (AL) e Montes Claros (MG) iniciaram e posteriormente se encerraram por conta dos protestos populares contra a transposição (BONI, 2005).

9 O território mineiro corresponde a 38\% da área total da Bacia; 70\% dos rios perenes; 48\% dos municípios; $59 \%$ da população e $70 \%$ do PIB, mas, segundo o Relator, Sepúlveda Pertence, este não tem ligação direta com o Projeto (ACO 876).

10 a) $\mathrm{OAB}$, seccional Sergipe e a $\mathrm{OAB}$, seccional da Bahia; b) Associação dos Catadores de Caranguejo do Povoado de Samarém (SE); c) Associação de Advogados de Trabalhadores Rurais no Estado da Bahia; d) Grupo Ambientalista da Bahia; e) Instituto de Ação Ambiental da Bahia; f) Associação Movimento Paulo Jackson; g) Centro de Estudos Ambientais; h) Associação dos Engenheiros Agrônomos da Bahia; i) Central Única dos Trabalhadores; j) Sindicato dos Trabalhadores na Indústria da Purificação e Distribuição de Água e em Serviços de Esgotos do Estado de Sergipe; k) Associação de Desenvolvimento Sustentável dos Pescadores e Moradores da Ilha do Cabeço; l) Colônia de Pescadores da Z8. A OAB/SE e OAB/BA são partes ilegítimas, segundo o Ministro, pois, no caso, seria parte legítima o Conselho Federal da OAB, conforme prescreve o art. 57, da Lei n. 8.906/94. Todas as demais entidades referidas foram consideradas partes ilegítimas por não constarem em suas finalidades estatutárias a defesa do meio ambiente, requisito formal previsto no art. $5^{\circ}$, da Lei n. $7.347 / 85$. Este requisito formal não é considerado imprescindível em inúmeros casos.

11 Foram realizados o Fórum de Avaliação do Plano, em Brasília (15-16/04/2004), além das reuniões sistemáticas em Brasília e nas cidades: Maceió (AL), Belo Horizonte (MG), Pirapora (MG), Ibotirama (BA), Juazeiro (BA), Santa Maria da Vitória (BA) e Salgueiro (PE), compreendendo as quatro regiões fisiográficas da Bacia (COMITÊ DA BACIA HIDROGRÁFICA DO RIO SÃO FRANCISCO, 2004-2013). Também foram feitas duas rodadas de discussões sobre o plano. A primeira de 11 a 22/03/2004, em Belo Horizonte (MG), Pirapora (MG), Ibotirama (BA), Juazeiro (BA) e Maceió (AL) e a segunda no período de 17 a 27/05/2004, em: Belo Horizonte (MG), Pirapora (MG), Santa Maria da Vitória (BA), Salgueiro (PE) e Aracaju (SE).

12 Segundo Bahia (2006) não houve qualquer recurso ao Conselho Nacional de Recursos Hídricos desta decisão.

13 A outorga preventiva foi concedida pela ANA, em 18/01/2005, por meio da Resolução ANA n. 29, nos mesmos termos da definitiva. E quando da aprovação do "aproveitamento hídrico" para o Projeto de Transposição, por meio da Resolução CNRH 47, de 17/01/2005 tendo como base a Nota Técnica 492/2004, da ANA, de 23/09/2004, as ilegalidades já despontavam. Neste sentido, Bahia (2006) destaca que os considerandos da resolução do CNRH nem sequer citam o Plano da Bacia do rio São Francisco. De acordo com a autora, a Nota Técnica nega as decisões contidas no Plano de Recursos da Bacia, no que se refere ao limite para alocação para usos consuntivos (decisão da III Plenária CBHSF, de junho 2004) e foi elaborada em data anterior à aprovação das prioridades, limites e critérios para usos externos (IV Plenária CBHSF, de outubro 2004). 
14 A Resolução Conama n. 237/97, em seu art. 19, arrola os casos de suspensão ou cancelamento das outorgas.

15 "O Vale do São Francisco possui aproximadamente 30 milhões de hectares de terras aptas para a agricultura irrigada. Adotando-se como fatores limitantes uma distância máxima de $60 \mathrm{~km}$ da fonte de água e uma elevação máxima de até $120 \mathrm{~m}$, o potencial irrigável no vale resulta em aproximadamente 8,1 milhões de hectares. A irrigação deste montante de terras já seria suficiente para consumir uma vez e meia toda a água produzida na bacia. Atualmente, estão implantados na bacia do rio São Francisco aproximadamente 340.000 hectares de agricultura irrigada" (SOCIEDADE BRASILEIRA PARA O PROGRESSO DA CIÊNCIA, 2004, p. 7).

16 Na versão preliminar do Plano, foi apresentada uma proposta de alocação espacial por Unidade da Federação, resultante do estudo elaborado pela equipe técnica da ANA e consultores do Projeto GEF São Francisco com a participação de representantes dos órgãos gestores dos Estados, da CODEVASF e da CHESF. Esta proposta e os valores que a embasaram foram objetos de contestação nas reuniões da Diretoria Colegiada, da Câmara Técnica de Planos, Câmara Técnica de Outorga e, principalmente, das Câmaras Consultivas Regionais do Médio (baixo), Submédio e do Baixo, por ocasião da $2^{a}$ Rodada de Discussão do Plano. A principal contestação diz respeito à não concordância com o conceito de partilha/delegação da gestão das águas do rio São Francisco que, a depender do trecho considerado, seria gerenciado por um único Estado ou por dois Estados, sendo que, neste último caso, cada metade do rio estaria submetida à gestão de um deles. Esta concepção conflita com o esforço desenvolvido pelo CBHSF em promover o conceito de gestão e planejamento integrados da bacia e comprometeria a própria razão de ser da sua futura Agência de Bacia (COMITÊ DA BACIA HIDROGRÁFICA DO RIO SÃO FRANCISCO, 2004).

17 Pinheiro e Rotzsch (2005a) mencionam que os (então) governadores de Estados beneficiados defendem a Transposição: Lúcio Alcântara (PSDB), do CE; Cássio Cunha Lima (PSDB), da PB; Jarbas Vasconcelos (PMDB), de PE e, Wilma de Faria (PSB), do RN. Os (então) governadores dos Estados onde o rio passa naturalmente condenam a obra: João Alves Filho (PFL), do SE; Paulo Souto (PFL) e Ronaldo Lessa (PDT), de AL.

18 Em suma, impactos ambientais são as alterações toleráveis, sejam positivas, sejam negativas; elas ocorrem a todo o momento. Danos são os eventos que extrapolam os limites da tolerabilidade. Entre riscos, danos e impactos há uma relação de causa e efeito, mas eles não se confundem, pois riscos não são danos, tampouco impactos e vice-versa. Os riscos ambientais podem acontecer ou não, estão fundados na potencialidade.

\section{REFERÊNCIAS BIBLIOGRÁFICAS}

AB'SÁBER, Aziz Nacib. Sobre a transposição do São Francisco. As águas do rio não são a panaceia para os problemas do Semiárido. Scientific American Brasil, São Paulo, ano 3, n. 35, p. 98, abr. 2005a.

A quem serve a transposição? Folha de S.Paulo, São Paulo, p. A18, 20 fev. 2005b.

ALENCAR, Bernardo; BRASILINO, Luís. Transposição revolta população. Brasil de Fato, Belo Horizonte, p. 6, 10-16 fev. 2005.

BAHIA, Carolina Medeiros. O Projeto da integração do rio São Francisco às bacias do Nordeste Setentrional e a Lei $n$. 9433/1997. 2006, 22p. (datilografia).

BANCO MUNDIAL. Relatório sobre o Projeto de Transposição do rio São Francisco. 11p. Disponível em: <http://www.cbhsaofrancisco.org.br>. Acesso em: out. 2007.

BECK, Ulrich. La sociedad del riesgo global. Madrid: Siglo Veintiuno de España Editores, 1999, 290p.

BOBBIO, Norberto. A era dos direitos. Rio de Janeiro: Campus, 1992, 217p.

BONALUME NETO, Ricardo. Sucesso depende de saneamento básico. Folha de S.Paulo, São Paulo, p. especial 2, 9 out. 2005

BONI, Ana Paula. Governo quer levar água para 12 milhões de pessoas. Folha de S.Paulo, São Paulo, p. especial 4, 9 out. 2005.

BRITO, Pedro. Água para todos. Folha de S.Paulo, São Paulo, p. A18, 20 fev. 2005.

CANOTILHO, José Joaquim Gomes. Estudos sobre direitos fundamentais. Coimbra: Coimbra Editora, 2004. 
CAUBET, Christian Guy; ARAújO, José Theodomiro de. Le transfert des eaux du fleuve São Francisco. Écologie \& Politique, n. 29, p. 153-169, 2004.

CENTRO DE RECURSOS AMBIENTAIS DA BAHIA. Parecer Técnico 1028/2004. Salvador, 2004. 100p.

Disponível em: http://www.ana.gov.br/cbhsaofrancisco/index.htm. Acesso em: out. 2007.

COELHO, Marco Antônio Tavares. A transamazônica de Lula. Correio Braziliense, Brasília, 27 set. 2004.

Disponível em: <http://www.risf.ana.gov.br>. Acesso em: 10 set. 2006.

COELHO, Marco Antônio Tavares. Projeto beneficia privilegiados. Folha de S.Paulo, São Paulo. p. especial 5, 9 out. 2005.

COMITÊ DA BACIA HIDROGRÁFICA DO RIO SÃO FRANCISCO. Plano Decenal de Recursos Hídricos da Bacia do rio São Francisco 2004-2013 (PBHSF) 337p. Disponível em: <http://cbhsaofrancisco.org.br>. Acesso em: out. 2007.

FONTES, Luis Carlos. Transposição: água para todos ou água para poucos? Anatomia da maior fraude hídrica e o conflito federativo de uso da água no Brasil. Revista do Comitê de Bacia Hidrográfica do rio São Francisco, Salvador, n. 1 , p. 60-73, set. 2007.

HENKES, Silviana L. As decisões político-jurídicas frente à crise hídrica e aos riscos: lições e contradições da transposição do rio São Francisco. Florianópolis, 2008. 451p. Tese de Doutorado. Curso de Pós-Graduação em Direito, Universidade Federal de Santa Catarina. Florianópolis.

HESSE, Konrad. A força normativa da Constituição. Porto Alegre: Sergio Antonio Fabris Editor, 1991.

LEITE, Marcelo. Política serve projetos de tempos em tempos. Folha de S.Paulo, São Paulo, p. especial 7, 9 out. 2005.

MACEDO, Rômulo. A visão do governo federal sobre o Projeto de Integração de Bacias. Revista do Comitê de Bacia Hidrográfica do rio São Francisco, Salvador, n. 1. p. 74-75, set. 2007.

MARCONDES, Neusa; ANDRADE, Marília Freire de. A história se repete. Como tragédia ou como comédia. In: DOWBOR, Ladislau; TAGNIN, Renato Arnaldo (Orgs.). Administrando a água como se fosse importante. Gestão Ambiental e sustentabilidade. São Paulo: Senac, 2005, p. 73-79.

MEDEIROS, Yvonilde. Processo de construção do plano da bacia hidrográfica do rio São Francisco. Revista do Comitê de Bacia Hidrográfica do rio São Francisco, Salvador, n. 1. p. 15-22, set. 2007.

MINISTÉRIO DA INTEGRAÇÃO NACIONAL et al. Resumo expandido do relatório do grupo de trabalho interministerial para analisar e propor um sistema operacional sustentável para o projeto de integração de águas do rio São Francisco com as bacias hidrográficas do Nordeste Setentrional. Brasília, 2004a. Disponível em:

<http://www.integracao.gov.br/saofrancisco>. Acesso em: 7 set. 2006.

MINISTÉRIO DA INTEGRAÇÃO NACIONAL. Relatório de impacto ambiental da transposição. Brasília, jul. 2004b, 136p. Disponível em: <http://www.integracao.gov.br>. Acesso em: out. 2007.

NORONHA, Silvia. Professor condena transposição do São Francisco. Correio da Bahia, Salvador, 25 out. 2004. Disponível em: <http://www.risf.ana.gov.br>. Acesso em: 15 set. 2006.

POMPEU, Carolina. Suspensa a transposição do São Francisco. Notícias do Ministério Público Federal. Disponível em: <http://noticias.pgr.mpf.gov.br/noticias-dosite>. Acesso em: 11 dez. 2007.

PINHEIRO, Márcio; ROTZSCH, Rodrigo. Entre doadores e receptores o Nordeste se divide. Folha de S.Paulo, São Paulo, p. especial 2, 9 out. 2005a.

PINHEIRO, Márcio; ROTZSCH, Rodrigo. Obra pode funcionar como trunfo eleitoral para Lula. Folha de S.Paulo, São Paulo, p. especial 2, 9 out.2005b.

SALOMON, Marta. Estudo vê pontos negativos no São Francisco. Folha de S.Paulo, São Paulo, 24 set. 2004. Disponível em: <http://www.risf.ana.gov.br>. Acesso em: 10 set. 2006.

SARLET, Ingo Wolfgang; FENSTERSEIFER, Tiago. A natureza de direito-dever da norma jusfundamental ambiental. Revista de Direito Ambiental, ano 17, n. 67, jul.-set. 2012, p. 11-70.

SOCIEDADE BRASILEIRA PARA O PROGRESSO DA CIÊNCIA, Encontro Internacional sobre transferência de águas entre grandes bacia hidrográficas. Workshop sobre a Transposição de águas do rio São Francisco. Relatório das discussões. Recife, out. 2004. 16p. Disponível em: http://www.risf.ana.gov.br. Acesso em 20/09/2006.

SUASSUNA, João. Rio São Francisco: conflitos nos usos de suas águas. Recife, jun. 1999. Disponível em: <http://www.fundaj.gov.br/>. Acesso em: 20 jun. 2005. 15p.

VILLA, Marco Antônio. Transposição: uma idéia ultrapassada. Folha de S.Paulo. São Paulo, p. 13, 16 fev. 2005. VILLA, Marco Antônio. Um projeto de quase 2 séculos. Estado de S.Paulo, São Paulo, 4 fev. 2004. Disponível em: <http://www.ana.gov.br>. Acesso em: out. 2007. 
TAbela 2 - Os impactos da transposição do Rio SÃo Francisco

\begin{tabular}{|c|c|c|c|c|}
\hline IMPACTOS & $\begin{array}{l}\text { FASE DE } \\
\text { PLANEJAMENTO }\end{array}$ & $\begin{array}{l}\text { FASE DE } \\
\text { CONSTRUC̣ÃO }\end{array}$ & $\begin{array}{l}\text { FASE DE } \\
\text { OPERAÇÃO }\end{array}$ & $\begin{array}{l}\text { NATUREZA } \\
\text { POSITIVO/ } \\
\text { NEGATIVO }\end{array}$ \\
\hline $\begin{array}{l}01 \text { INTRODUCCÃO DE TENSÕES E RISCOS } \\
\text { SOCIAIS DURANTE A CONSTRUCÃO }\end{array}$ & $x$ & $x$ & & - \\
\hline
\end{tabular}

02 RUPTURA DE RELACָ̃̃ES

SOCIOCOMUNITÁRIAS DURANTE A FASE

DE OBRA

$x$

03 POSSIBILIDADE DE INTERFERÊNCIAS

COM POPULAÇÕES INDÍGENAS

$x \quad x$

04 RISCO DE ACIDENTES COM

A POPULAÇÃO

\begin{tabular}{lccc}
\hline 05 AUMENTO DAS EMISSÕES DE POEIRA & $x$ & $x$ & - \\
\hline 06 AUMENTO E/OU APARECIMENTO & & & \\
DE DOENÇAS & $x$ & $x$ & - \\
\hline
\end{tabular}

07 AUMENTO DA DEMANDA POR

INFRA-ESTRUTURA DE SAÚDE

$x$

08 PERDA DE TERRAS POTENCIALMENTE

AGRICULTÁVEIS

$x$

09 PERDA TEMPORÁRIA DE EMPREGOS E

RENDA POR EFEITO DAS DESAPROPRIAÇÕES

$x$

10 INTERFERÊNCIAS COM ÁREAS

DE PROCESSOS MINERÁRIOS $X$

\begin{tabular}{|c|c|c|c|}
\hline $\begin{array}{l}11 \text { GERAÇÃO DE EMPREGOS E RENDA } \\
\text { DURANTE A IMPLANTAÇÃOO }\end{array}$ & $x$ & & + \\
\hline 12 DINAMIZAÇÃO DA ECONOMIA REGIONAL & $x$ & $x$ & + \\
\hline $\begin{array}{l}13 \text { PRESSÃO SOBRE A INFRA-ESTRUTURA } \\
\text { URBANA }\end{array}$ & $x$ & $x$ & - \\
\hline
\end{tabular}

14 ESPECULAÇ̃̃O IMOBILIÁRIA NAS

VÁRZEAS POTÉNCIALMENTE IRRIGÁVEIS

NO ENTORNO DOS CANAIS

$x$

$x$

15 RISCO DE INTERFERÊNCIA COM

O PATRIMÔNIO CULTURAL

$x$

$x$

16 AUMENTO DA OFERTA E

DA GARANTIA HÍDRICA

X +

17 AUMENTO DA OFERTA DE ÁGUA

PARA ABASTECIMENTO URBANO

18 ABASTECIMENTO DE ÁGUA

DAS POPULAÇÕES RURAIS

19 REDUÇÃO DA EXPOSIC̣ÃO DA POPULAÇÃO

A SITUAÇÕES EMERGENCIAIS DE SECA

$X$

$X$

$+$ 
20 DINAMIZACÃO DA ATIVIDADE AGRÍCOLA E INCORPORÁĊ̃̃O DE NOVAS ÁREAS AO PROCESSO PRODUTIVO

X +

21 DIMINUIC̣ÃO DO ÊXODO RURAL E

DA EMIGRAC̣ÃO DA REGIÃO

$x$

X +

22 REDUÇÃO DA EXPOSIÇÃO DA POPULAC̣ÃO

A DOENÇAS E ÓBITOS

23 REDUĈ̃̃ DA PRESSÃO SOBRE

A INFRA-ESTRUTURA DE SAÚDE

24 PERDA E FRAGMENTAÇÃO DE CERCA DE 430 HECTARES DE ÁREAS COM VEGETAÇÃO NATIVA E DE HÁBITATS DE FAUNA TERRESTRE

25 DIMINUICTÃO DA DIVERSIDADE DE FAUNA TERRESTRE

$X$

$X$

$x$

26 AUMENTO DAS ATIVIDADES DE CAC̣A

E DIMINUICCÃO DAS POPULAÇÕES

DAS ESPÉĆIES CINEGÉTICAS

$x$

27 MODIFICAC̣ÃO DA COMPOSIC̣ÃO DAS

COMUNIDADES BIOLÓGICAS AQUÁTICAS

NATIVAS DAS BACIAS RECEPTORAS

$X$

28 RISCO DE REDUÇÃO DA BIODIVERSIDADE

DAS COMUNIDADEŚ BIOLÓGICAS AQUÁTICAS

NATIVAS NAS BACIAS RECEPTORAS

$X$

29 COMPROMETIMENTO DO CONHECIMENTO

DA HISTÓRIA BIOGEOGRÁFICA DOS GRUPOS

BIOLÓGICOS AQUÁTICOS NATIVOS

$X$

30 RISCO DE INTRODUÇÃO DE ESPÉCIES

DE PEIXES POTENCIALMENTE DANINHAS

AO HOMEM NAS BACIAS RECEPTORAS

31 INTERFERÊNCIA SOBRE A PESCA

NOS AÇUDES RECEPTORES

$X$

$+$ 
534 : A POLÍTICA, O DIREITO E O DESENVOLVIMENTO: UM ESTUDO SOBRE A TRANSPOSIÇÃO DO RIO SÃO FRANCISCO

39 MELHORIA DA QUALIDADE DA ÁGUA

NAS BACIAS RECEPTORAS

40 AUMENTO DA RECARGA FLUVIAL DOS AQÜÍFEROS

$x$ $x$

$+$

41 INÍCIO OU ACELERACุÃO DOS PROCESSOS DE DESERTIFICAC̣ÃO

$x$

42 MODIFICAÇÃO NO REGIME FLUVIAL

DO RIO SÃO FRANCISCO

$X$

$x$

$+$

43 REDUÇÃO DA GERAÇÃO DE ENERGIA

ELÉTRICÁ NO RIO SÃO FRANCISCO

44 DIMINUIC̣ÃO DE RECEITAS MUNICIPAIS X

$X$

Fonte: MINISTÉRIO DA INTEGRAÇÃO NACIONAL, 2004b, p. 75.

Silviana L. Henkes

silvi_henkes@ahotmail.com |

Pós-doutora em Direito pela Universidade FEDERAL DE UBERLÂNDIA DOUTORA EM DIREITO PELA UNIVERSIDADE Federal de Santa Catarina

EstáGIO dOUTORAL NA UnIVERSITÉ PARIS I E NA ÉCOLE des Hautes Études en Sciences Sociales/Paris

Professora do Mestrado em Direitos e GaRANTIAS FundamentaIS NA UniversidadE

FEDERAL DE UbERLÂNDIA 